\title{
Zoran Čučković
}

\section{Antički krajolik Bujštine: Primjena sustavnoga terenskog pregleda i pokušaj prostorne analize}

\author{
Izvorni znanstveni rad \\ Original scientific paper
}

UDK 904:712>(497.5-37 Buje) «652«

Predstavljeni su rezultati sustavnoga terenskog pregleda na prostoru Bujštine te potom njihova prostorna analiza u kontekstu istraženoga područja. Prethodno analizi razmotreni su problemi nastanka površinskoga arheološkog zapisa, odnosno dobivenoga skupa podataka. Na temelju jednostavne tipologije nalazišta (dva tipa) provjerena je njihova prostorna korelacija i raspored. Također su razmotrene mogućnosti rekonstrukcije pružanja jedne lokalne prometnice te teritorijalnih odnosa dokumentiranih naseobina. Pozornost je posvećena i nalazima izvan nalazišta.

Ključne riječi: sustavni terenski pregled, antika, vila rustika, prostorna arheologija, Istra, Bujština, arheološka metodologija

\section{UVOD}

Sustavnim terenskim pregledom zapadne Bujštine, zasad provedenim u zaleđu Umaga, ustanovljeno je više desetaka novih arheoloških nalazišta od čega većina datira u antičko razdoblje. lako su provedene tek tri sezone terenskoga pregleda (od 2007. do 2009. godine) i jedno probno geofizičko snimanje te su rezultati istraživanja u mnogome preliminarnoga karaktera, ipak raspolažemo razmjerno brojnim uzorkom čime se otvaraju mogućnosti prostorne analize.

Za poznavanje antičke topografije Bujštine najznačajniji su radovi A. Degrassija (1957) na antičkim pristaništima te topografija ruralne arhitekture R. Matijašića (1987). Dosta podataka pruža i A. Bendetti u preglednom radu o povijesti Umaga (Benedetti 1973). U novije je vrijeme poduzeto više značajnijih istraživačkih kampanja na prostoru u neposrednoj blizni pregledane zone koje uvelike nadopunjuju starija saznanja. U srednjovjekjovnoj jezgri Umaga dokumentiran je dio kasnoantičkoga gospodarskog sklopa namijenjen proizvodnji maslinova ulja (Bolšec-Ferri 2008: 107), a nedavno su istraženi antički lokaliteti Lovrečica (Bolšec-Ferri 2007), priobalna vila s dosta luksuznih elemenata u Sv. Ivanu (Katunarić 2009), ruralna građevina ispod crkve Sv. Lovre u Valfontani (Bekić et al. 2008) i veći antički objekt u Dajli (Markežić-Petrović 2009). Sva su navedena istraživanja zaštitnoga karaktera te detaljne analize zasad nisu dostupne. Za razumijevanje antičkoga zaleđa Bujštine vrlo je zanimljiv ruralni objekt otkriven u Kršetama kod Buja (Ujčić 2005; 2010) te također i ranije istražena nekropola u blizini (Matijašić 1997). U podmorju kod 
Savudrije otkrivena su dva antička brodoloma s teretom karakterističnih grčko-italskih amfora iz 2. - 1. st. pr. Kr. (Vrsalović 1974: 21, Zmaić 2007).

U usporedbi s ostatkom zapadne Istre, specifičnost je antičke Bujštine izostanak urbanoga središta, što je uvjetovalo donekle različit povijesni razvitak. Po svemu sudeći, to područje nije bilo centurijacijom podijeljeno u pravilne zemljišne čestice te vjerojatno nije doživjelo kolonizacijski val jednakoga zamaha kao ageri Pule i Poreča (Matijašić 1987: 92, Starac 1999: 122'). Međutim, epigrafski spomenici pokazuju sličan udio latinskih imena u onomastičkom korpusu kao i u okolci antičkih kolonija južne Istre (76\%), što nedvojbeno upućuje na usporediv stupanj kuturne preobrazbe, tj. romanizacije (Starac 1999: 120). Do sličnoga je zaključka došao i R. Matijašić analizom nekropole kod Kršeta (Matijašić 1997: 107). Iz epigrafskoga materijala također je razvidan značaj velikih senatorskih imanja uzduž sjeverozapadne obale Istre (npr. porodice Kalpurnija i Kornelija; Degrassi 1957: 50, Matijašić 1987: 93, Starac 1999: 85). Spomenimo spominjanje službenika ili činovnika (commentarensis) na natpisu iz Vilanije (IIt X/3 50) te nadglednika za održavanje štala (centenarius stabuli dominici) kod Novigrada (IIt X/3 53). Natpisi mogu biti datirani u 2. do 3. st., odnosno 4. st., te po A. Starac zajedno s ostalim podacima s toga prostora indiciraju osjetno kasniji razvoj carskih ili senatorskih imanja u sjevernoj Istri (1999: 85).

Prema iznesenim podacima, čini se da antičku Bujštinu karakterizira decentraliziran naseobinski sustav, orijentiran prije svega prema lučicama koje su se nalazile u gotovo svakom većem zaljevu. Neke se od priobalnih naseobina svakako mogu opredijeliti u raskošne vile maritime, poput iznimno prostranoga sklopa na rtovima Katoro i Tiola (Matijašić 1987: 79; 81), no vjerojatno se u većem dijelu pristanišnih sklopova može pratiti transformacija u lokalna rurarna središta, kao npr. u Sv. Ivanu, gdje je u izvorno raskošnu vilu u drugom ili trećem stoljeću postavljeno postrojenje za proizvodnju maslinova ulja (Katunarić 2009: 375). Podudaranje u osnovnim karakteristikama ruralnoga stanovništva s ostatkom zapadne Istre te organizacija prostora kroz krupne zemljoposjede vjerojatno upućuju na snažan utjecaj Akvileje, trgovačkog i strateškog središta antičke regije Venecije i Histrije.

Rijedak je primjer prostorne analize u kontekstu antičke arheologije Istre studija agera Pule i Poreča R. Matijašića (1988). U tom su radu razmotrena složena pitanja prostorne organizacije i demografije, a također je primijenjena analiza korelacije položaja nalazišta i centurijacijske sheme. Prema proračunu izrađenomu na temelju gustoće nalazišta Matijašić je prosječnu veličinu posjeda u agerima Pule i Poreča procijenio na oko 475 iugera, što je već blizu površine manje latifundije (Matijašić 1998: 309). Napučenost bi puljskoga agera u skladu s gustoćom ruralnih nalazišta iznosila oko 40000, a porečkoga oko 25000 stanovnika. Kolonije Pula i Poreč su, nadalje, imale razmjerno malene populacije: 4000 odnosno 1500 ljudi, prema čemu bi se mogle okarakterizirati kao »agrarni gradovi«, tj. naselja koja su u određenom smislu definirana okolnim agrarom (Matijašić 1988: 107).

Potpuno različit, geostatistički pristup primijenio je S. Poglajen $(2007,2009)$. On je uporabio cijeli niz analitičkih i statističkih metoda u okviru računalnoga sustava GIS (analiza naseobinskih jezgri (cluster analysis), optimalni putovi (optimal paths), različite prostorne korelacije, ekonomski potencijal itd.) na prostoru sjeverozapadne Istre od Trsta do Mirne. Od njegovih zaključaka izdvojili bismo prijedlog za trasiranje glavne istarske prometnice (via Flavia), istočno od Buja,

1 Rasprostranjeno je mišljenje da je Bujština bila uključena u tergestinski ager (Matijašić 1987: 93, Starac 2002: 274). Tragovi centurijacijske mreže nisu sa sigurnošću utvrđeni niti u neposrednoj okolici Trsta (Starac 1999: 34), no valja napomenuti da je centurijacija samo jedna od više mogućnosti prostorne organizacije antičkoga agrara (usp. parcelacije dokumentirane u sjeveroistočnoj Francuskoj: Georges-Leroy et al. 2007). Nadalje, po R. Matijašiću ovo područje nije bilo uključeno u kolonijski ager, tj. nije podvrgnuto takvomu režimu naseljavanja (Matijašić 1997: 107). 
preko naselja Triban (Poglajen 2009: 241). Na temlju statističke analize također je dokazao korelaciju prostora s dobrim agrarnim potencijalom i antičkih agrarnih naselja (Poglajen 2007: 136).

lako su pristupi R. Matijašića i S. Poglajena znatno različiti, ipak dijele određene zajedničke probleme koji mogu biti dobar izazov za sustavni terenski pregled. Uostalom, ova je metoda danas jedan od standardnih pristupa razmatranju antičkoga gospodarstva i demografije (usp. Dyson 2003: pogl. 2). U oba su rada problem »mala nalazišta«, tj. ona koja izlaze iz okvira tipičnih vila rustika. Doduše, S. Poglajen je pokušao izlučiti tu skupinu pomoću složene statističke analize, no prostorni je obrazac tih nalazišta teško interpretirati (Poglajen 2007: 96-97). Nedostatak je svakako u korpusu poznatih nalazišta koji je uglavnom dobiven slučajnim pronalascima, nasumičnim iskopavanjima i ekstenzivnim terenskim pregledom, te je sastavljen od velikih, uočljivih nalazišta, dok su ostali tipovi odveć slabo zastupljeni za podrobniju analizu. R. Matijašić je pak već ranije radio na tipologiji ruralnih naseobina (Matijašić 1982), no podaci su vjerojatno odveć nekonzistentni za uključivanje u analizu agera Pule i Poreča. Također je ključan problem mogućnost rekonstrukcije izvorne gustoće nalazišta na temelju postojećih podataka, u čemu je neophodan ne samo detaljan terenski rad, već i složena metodologija kojom je moguće razlučiti utjecaje različitih prirodnih i kulturnih čimbenika na očuvanje i otkrivanje arheoloških nalaza i nalazišta. Uspoređujući brojnost nalazišta na bolje dokumentiranim predjelima uz obalu između Pule i Rovinja, R. Matijašić procjenjuje da u najboljem slučaju raspolažemo jednom trećinom izvornoga naseobinskog obrasca (Matijašić 1988: 91, n 384).
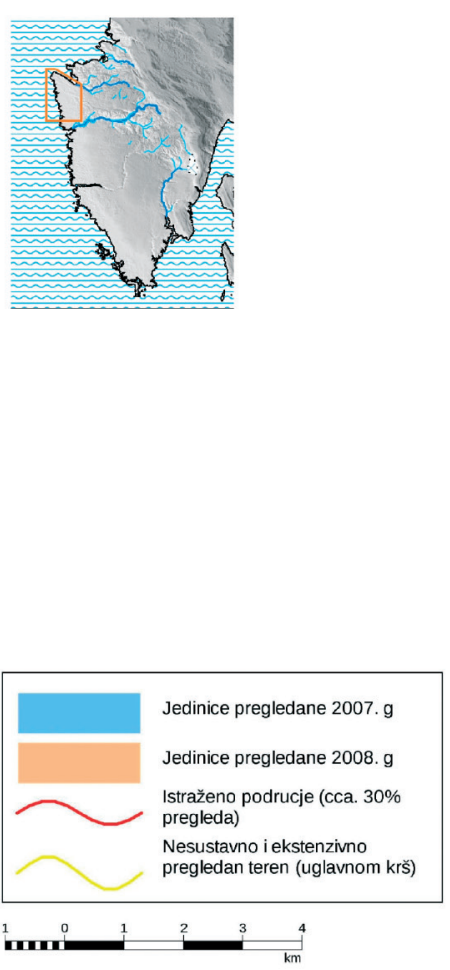

SI. 1. Istraženi prostor s današnjim naseljima

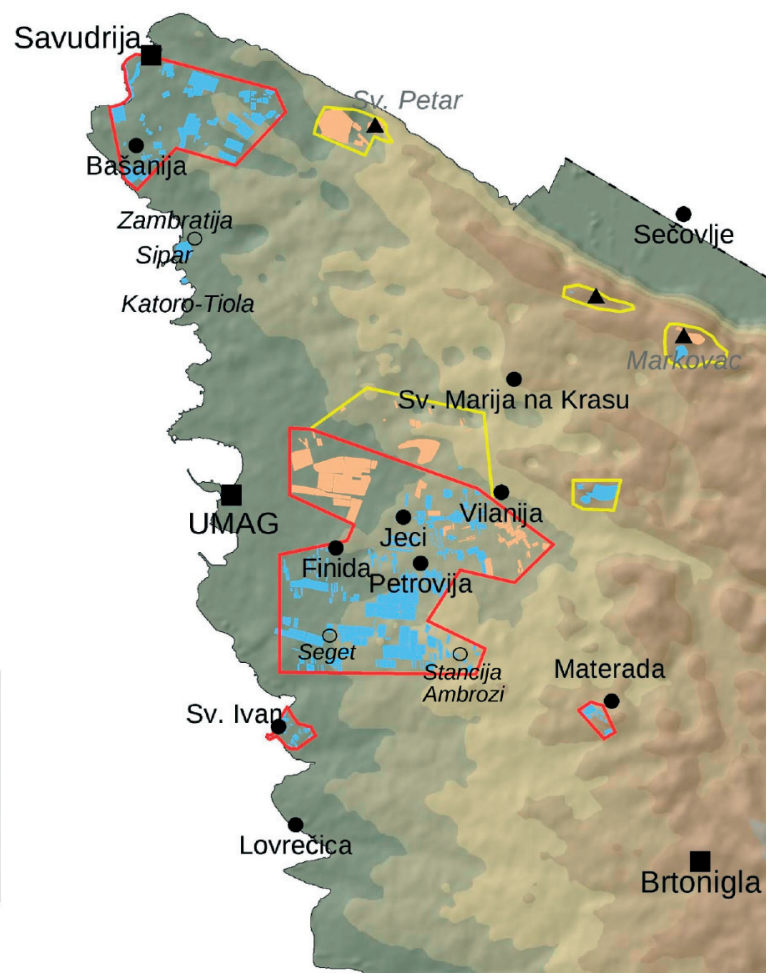




\section{POUZDANOST DOKUMENTIRANE DISTRIBUCIJE NALAZIŠTA}

\section{1) Metodologija terenskoga pregleda}

Područje Bujštine obuhvaća priobalni pojas prekriven crvenicom koji je razmjerno intenzivno poljoprivredno obrađen te vapnenački i flišni brežuljkasti krajolik u unutrašnjosti. Taj je prostor omeđen strmim dolinama Mirne i Dragonje na jugu i sjeveru, dok prema unutrašnjosti poluotoka ne postoji tako jasna geografska odrednica. Provedeno istraživanje usmjereno je na područje oko Umaga, odnosno na sjeverozapad Bujštine. Odabrane su dvije veće zone unutar kojih je proveden sustavni terenski pregled na pogodnim mjestima (uglavnom netom obrađenim poljoprivredenim površinama); zaleđe Savudrije i zaleđe Umaga te dva manja izdvojena područja oko Sv. Ivana i Materade (sl. 1). Sustavno je pregledano oko 25\% površine tih zona, odnosno 420 ha od oko 1600 ha, dok površina svih pregledanih lokacija iznosi 520 ha.

Metodologija terenskoga pregleda zapadne Bujštine detaljnije je analizirana u radu u pripremi (Čučković u tisku). Istraživanje je provedeno u tri kampanje, 2007. - 2009. godine, koje su organizirane s ponešto različitim ciljevima te se razlikuju u primijenjenoj metodologiji (Čučković 2008, 2010). U prvoj sezoni terenskoga pregleda, u kojoj je pronađena većina antičkih nalazišta, težište je postavljeno na što širi obuhvat te je u skladu s tim primijenjena nešto grublja metodologija (uglavnom pregled u razmacima od 15 do 25 metara između pregledavača). Sljedeće je sezone intenzitet pregleda pojačan na pregled u rasporedu od isključivo 15 m s detaljnim dokumentiranjem nalaza izvan nalazišta u svakoj prehodanoj liniji (sl. 9). Arheološka su nalazišta uglavnom dokumentirana pregledom u linijama na razmaku od 2,5 do 5 metara ili nešto šire, ovisno o poljoprivrednom nasadu, a koncentracije površinskih nalaza su prebrojavane po minuti pregleda, što odgovara duljini od tridesetak metara (Prilog 3). Tehnike intenzivnoga prikupljanja nalaza (npr. u mreži kvadranata) primijenjene su samo na dva odabrana nalazišta budući da je riječ o pristupu koji je vremenski vrlo zahtjevan, naročito kada se otkrivena nalazišta broje u desetcima. Detaljniji pristup usmjeren na pojedina nalazišta planiran je u nastavku istraživanja, što je već započeto primjenom geofizičkoga snimanja 2009. godine. Uslijed primijenjene strategije istraživanja, kao i zbog relativnoga siromaštva površinskih nalazišta izuzev nekoliko slučajeva svježe destrukcije, raspolažemo razmjerno slabim uzorkom nalaza, uglavnom loše očuvanom grubom, lokalnom lončarijom.

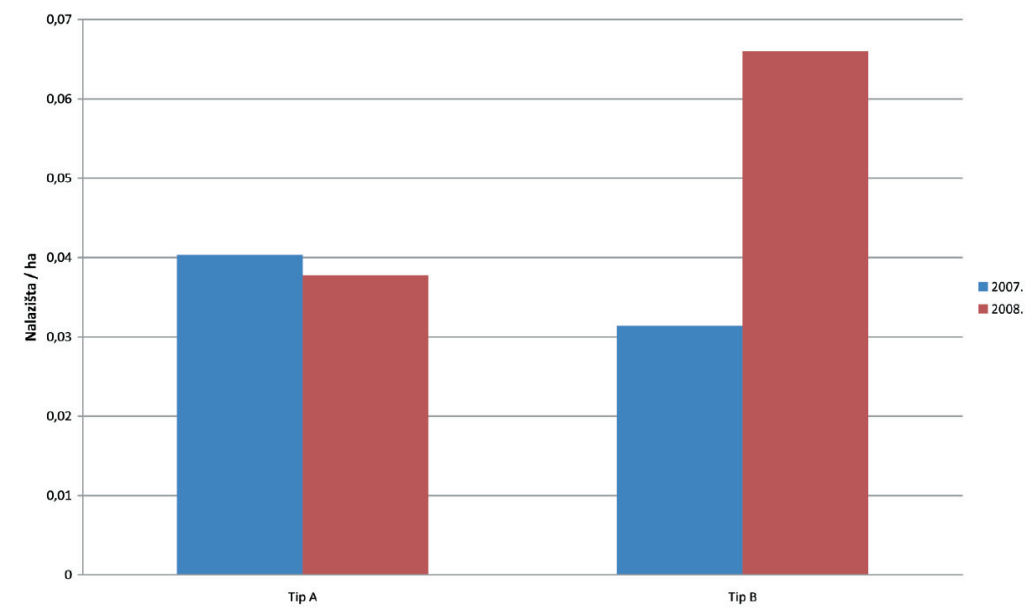

SI. 2. Uspješnost u otkrivanju različitih tipova nalazišta po kampanjama istraživanja 


\begin{tabular}{|c|c|c|c|}
\hline Sezona pregleda & Pregledana površina (ha) & Tip A & Tip B \\
\hline 2007. & 223 & 9 & 7 \\
\hline 2008. & 106 & 4 & 7 \\
\hline
\end{tabular}

Tablica 1. Uspješnost detekcije antičkih nalazišta na prostoru umaškoga zaleđa.

Može se očekivati da će intenziviranje terenskoga pregleda polučiti veći broj nalazišta, što je i razvidno iz usporedbe prve i druge sezone istraživanja na sl. 2. U analizu su uvrštena antička nalazišta iz najvećega bloka pregledanoga terena u zaleđu Umaga, a razvrstana su u dvije skupine: Tip A - velika nalazišta i Tip B - mala nalazišta (tipologija je razmotrena niže u tekstu). Zanimljivo je da je intenzivnijom metodologijom poboljšan uspjeh pronalaska samo teže uočljivih nalazišta, u pravilu i manje površine. Razliku u uspjehu u detekciji nije moguće kvantitativno izraziti zbog nekoliko razloga, prije svega malenoga uzorka te potom i mogućnosti stvarnih varijacija u distribucijama površinskih nalazišta. U svakom slučaju, može se zaključiti da su obje sezone usporedive po učinkovitosti pronalaska većih nalazišta, što je od značaja za primjenu prostornih analiza. Diskrepancija koja je u potpunosti ograničena na skupinu teže uočljivih nalazišta može indicirati izravnu ovisnost njihove detekcije o primijenjenoj metodologiji. Čini se manje vjerojatno da bi gustoća manjih nalazišta bila neovisna o distribuciji većih nalazišta, tim više što je moguće dokazati njihovu prostornu korelaciju (cf. infra). Prema tome zaključujemo da gustoća manjih nalazišta ne ocrtava vjerodostojno očekivano stanje antičke topografije, barem u rezultatima prve sezone pregleda. Budući da intenzitet pregleda ima učinak sustavnoga uzorkovanja krajolika, prostorni raspored tih nalazišta ipak može i dalje ostati pouzdan čimbenik, iako njihovu brojnost nije moguće točnije odrediti.

\section{2) Formacijski procesi}

Pojedini su problemi nastanka (i nestanka) površinskih nalazišta na istraženom prostoru već razmotreni u radu u pripremi (Čučković u tisku). Valja naročito istaknuti značaj dubinskoga oranja (rigolanja) te promjenâ u parcelacijskoj mreži. Takvim izrazito destruktivnim agrarnim mjerama najveći zamah pratimo između 1960-ih i 1980-ih, kada su mnoge površine zasađene vinovom lozom i maslinom te u manjoj mjeri ostalim kulturama. S tim su u svezi i učestali izvještaji arheologâ Arheološkoga muzeja Istre o svježe devastiranim nalazištima iz razdoblja 1960-ih i 1970-ih godina (Mlakar 1979, Matijašić 1987). Spominje se više razmjerno bogatih nalazišta s tragovima arhitekture, brojnim nalazima lončarije, novca i sl. Međutim, kroz dulji period površinski se nalazi usitnjavaju i homogeniziraju, a rijetke vrste nalaza poput novčića ili stakla iščezavaju. Dobar primjer pruža nalazište u blizini zaseoka Makale, koje je objavio Š. Mlakar, a koje smo identificirali s nalazištem Petrovija 8 (Prilog 1: 19). Mlakar je objavio više ulomaka tegula sa žigom te izvijestio o nalazima amfora, dolija, kućne keramike i ostatcima arhitekture (Mlakar 1979: 35-37). R. Matijašić donosi, također s istoga područja, izvještaje o nalazu nadgrobne stele i kamenih potporanja (stipites) tijesaka za masline (Matijašić 1987: 84). Prilikom terenskoga pregleda Bujštine na lokaciji Petrovija 8 uočen je tek vrlo difuzan skup usitnjenih keramičkih fragmenata u zapuštenu vinogradu.

Recentne promjene u strukturi parcelacijskoga rastera također mogu uzrokovati značajne poteškoće pri tumačenju površinskih arheoloških distribucija. Naime, zemljišne su međe tipično mjesto odlaganja neželjenoga materijala s polja među kojim nerijetko ima i arheoloških nalaza (usp. Bintliff et al. 1989: 50). Uklapanje tih međa, odnosno bokaža koji se ondje stvara stoljetnim održavanjem obradivih površina, u veće, za mehanizaciju pogodne površine, ima za posljedicu 
daljnje raspršivanje arheološkoga materijala koji se ondje nakupio. Mogućnost stvaranja »lažnih nalazišta« tim putem razmotrena je u radu u pripremi (Čučković u tisku).

Naročit je problem kod tumačenja rezultata sustavnoga površinskog pregleda korelacija dokumentiranih prostornih obrazaca s općim stanjem očuvanosti površinskoga arheološkog zapisa. Stoga je korisno razlučiti karakteristične tipove lokalnoga agrara i razmotriti njihov utjecaj na kvalitetu dobivenih podataka. U tu se svrhu pregledani teren može okvirno podijeliti u tri agrarna tipa: vinograde i maslinike, zatim manje površine mješovitoga, obiteljskog gospodarstva te široke površine zasađene komercijalnim, jednogodišnjim kulturama. Zona vinograda i maslinika karakteristična je za područje između Segeta, Makala i Petrovije te je dobrim dijelom vezana uz bivša zemljišta PIK-a Umag. Riječ je o terenu razmjerno povoljnom za površinski pregled s kontinuiranim, širokim površinama sa sličnim stanjem tla te osrednje do dobro vidljivim površinskim nalazima. Dubinsko oranje koje prethodi sadnji izbacuje velike količine arheološkoga materijala na površinu, a sezonski radovi nakon toga znatno su slabijega intenziteta iako uključuju proljetno uzoravanje te u kraćem razdoblju održavaju površinsku vidljivost nalazišta. Najbolji su uvjeti svakako na svježe zasađenim površinama, dok je naročit problem zapuštanje zasada koje je učestalo kod slabo isplativih PIK-ovih vinograda. U konačnici je moguće procijeniti da će na prostoru pod takvim poljoprivrednim režimom vladati uvjeti koji su donekle povoljni za detekciju širih prostornih obrazaca, no kvaliteta dobivenih nalaza može varirati ovisno o starosti zasada i stanju obrađenosti. Drugi je režim, koji je karakterističan prije svega za neposrednu okolicu seoskih naselja, iznimno heterogen te uključuje mnogo različitih vrsta poljoprivrednih zasada i režima. Unatoč tomu, vidljivost površinskih nalaza može biti razmjerno dobra pod uvjetom dobre poljoprivredne obrađenosti. Ukoliko je organizacija pregleda u stanju prevladati rascjepkanost takvoga prostora, tj. osigurati gust raspored pregledanih jedinica, moguće je očekivati donekle pouzdan prostorni obrazac, no kvaliteta nalaza zasigurno će jako varirati, a dobar dio nalazišta neće biti pregledan u cijelosti. Na poljoprivrednim površinama zasađenima jednogodišnjim kulturama poljoprivredni su radovi znatno jačega intenziteta te također i izmjene zemljišnih podjela, što rezultira znatno ubrzanim procesom degradacije. To može biti uzrok iznimno slabomu stanju površinskih lokaliteta u neposrednom zaleđu Umaga, između naselja Špinel i Jeci, koje je pregledano 2008. godine. Ondje su zabilježene vrlo difuzne koncentracije površinskih nalaza, često bez ikakvih uočljivih karakteristika (npr. promjene u boji tla, prisutnost kamena i sl.) te je veći dio nalazišta dokumentiran istom metodom kao i nalazi izvan nalazišta. S druge strane, homogenost i kontinuiranost obrađenih površina može osigurati vrlo dobre uvjete za uočavanje prostornih obrazaca, ne samo pojedinih nalazišta, već i nalaza izvan nalazišta. Također je i vidljivost površinskih nalaza vrlo dobra, zahvaljujući prije svega finijoj obradi, no u slučaju umaškoga zaleđa problem je u predugom razdoblju destrukcije.

U svrhu kvantitativne analize utjecaja spomenutih agrarnih zona na rezultate terenskoga pregleda pokušali smo ih usporediti po gustoćama sadržanih nalazišta (tab. 2). Valja naglasiti da je iscrtavanje tih zona značajno pojednostavljen prikaz inače vrlo heterogenoga poljoprivrednog krajolika. Neobično je da je pregled polučio veću gustoću nalazišta na mješovitom agrarnom tipu, unatoč značajnoj rascjepkanosti zemljišnih čestica i heterogenosti krajolika. Dobivene vrijednosti valja uzeti s rezervom, s obzirom na nepravilnu distribuciju arheoloških nalazišta, ali budući da donekle odgovaraju intenzitetu mehanizirane poljoprivrede, pretpostavljamo da je taj čimbenik povezan s uspjehom u detekciji antičkih nalazišta.

Kada je riječ o kvaliteti površinskih nalaza, također valja očekivati značajnu ovisnost o poljoprivrednom režimu. To je vidljivo iz usporedbe najviših gustoća površinskih nalaza pojedi- 


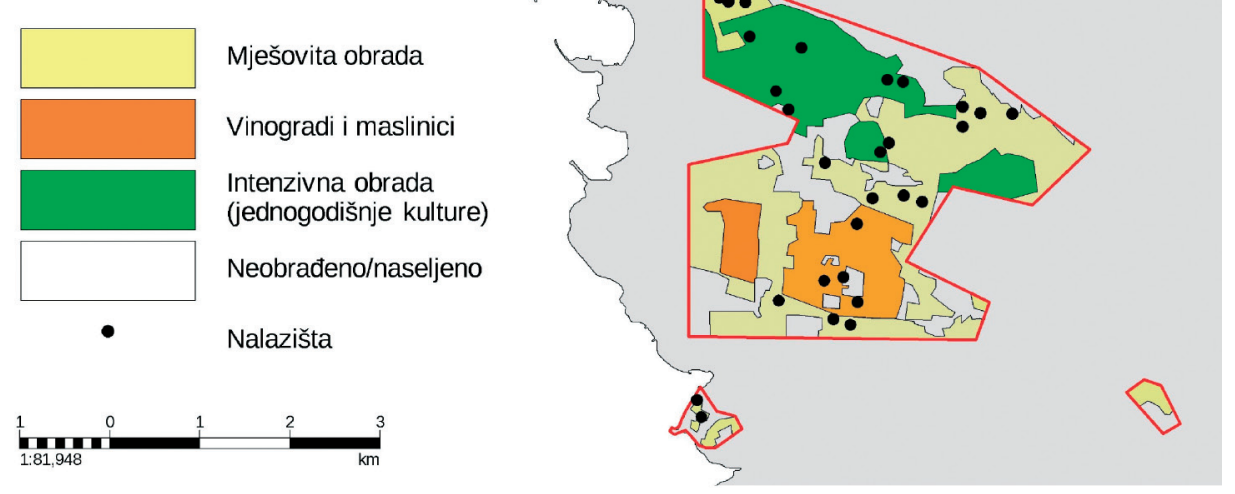

SI. 3. Tri osnovna agrarna tipa na istraženom području

\begin{tabular}{|c|c|c|c|}
\hline Agrarni tip & Mješoviti tip & $\begin{array}{r}\text { Vinogradi/ } \\
\text { maslinici }\end{array}$ & $\begin{array}{r}\text { Intenzivna } \\
\text { obrada }\end{array}$ \\
\hline $\begin{array}{l}\text { Ukupna površina zona sustavnoga } \\
\text { pregleda (ha) }\end{array}$ & 764 & 187 & 296 \\
\hline $\begin{array}{l}\text { Pregledana površina u zonama } \\
\text { sustavnoga pregleda (ha) }\end{array}$ & 219 & 90 & 114 \\
\hline $\begin{array}{l}\text { Broj antičkih nalazišta pronađenih } \\
\text { sustavnim pregledom (bez } \\
\text { nepouzdanih) }\end{array}$ & 21 & 4 & 7 \\
\hline $\begin{array}{l}\text { Gustoća antičkih nalazišta u } \\
\text { pregledanoj površini (po km²) }\end{array}$ & 0,1 & 0,04 & 0,06 \\
\hline $\begin{array}{l}\text { Prosjek najviših gustoća } \\
\text { površinskih nalaza (po nalazištu) }\end{array}$ & $28 \mathrm{kom} / \mathrm{min}$ & $69 \mathrm{kom} / \mathrm{min}$ & $7 \mathrm{kom} / \mathrm{min}$ \\
\hline St. dev. $(\sigma)$ & 24,2 & 39,5 & 5,1 \\
\hline
\end{tabular}

Tablica 2. Analiza utjecaja poljoprivrednoga režima na kvalitetu površinskoga arheološkog zapisa 
načnih nalazišta (tab. 2). Dobivene su vrijednosti dijelom uvjetovane usmjeravanjem intenzivne metode u drugoj sezoni pregleda na prostor pod intenzivnim poljoprivrednim režimom, uslijed čega je otkriven veći broj manjih nalazišta sa slabijim površinskim koncentracijama nego u prijašnjoj kampanji. Ta činjenica, međutim, ne može u potpunosti objasniti dokumentiranu diskrepanciju te vjerujemo da navedeni iznosi dovoljno jasno indiciraju utjecaj poljoprivredne obrade na brojnost, te posredno i na raznovrsnost, površinskih nalaza.

\section{REZULTATI PREGLEDA}

\section{Tipovi nalazišta}

Gotovo sva pronađena antička nalazišta koncentracije su površinskih nalaza na oranicama. Takva je situacija dijelom ishod strategije istraživanja koja je bila usmjerena na poljoprivredno zaleđe Umaga, no svakako je i odraz nesumnjive agrarne orijentacije antičkoga gospodarstva. Ukupno je na području sjeverozapadne Bujštine registrirano 39 antičkih nalazišta različitih veličina i različitoga stupnja pouzdanosti (Prilog 1: katalog nalazišta²), od kojih ćemo ukratko prezentirati nekoliko bolje očuvanih primjera.

Analiza formacijskih procesa pokazala je izrazita odstupanja u stupnju očuvanosti površinskih nalazišta odnosno u pouzdanosti njihove prostorne distribucije. U svrhu uspostavljanja pouzdane klasifikacijske sheme svakako je potrebno odabrati karakteristike koje su najmanje ovisne o postdepozicijskim promjenama. Tako je, na primjer, prisutnost rjeđih tipova površinskih nalaza (metal, staklo i sl.) jednako ovisna o poljoprivrednom režimu i ostalim formacijskim procesima koliko i o izvornoj namjeni nalazišta. Čini se pouzdanije promatrati veličinu površinskih koncentracija, iako je i ona donekle ovisna o poljoprivrednoj obradi (Taylor 2000: 23). Veći je problem u tom slučaju djelomična dokumentiranost većine nalazišta, budući da se ona vrlo često nalaze na više zemljišnih čestica pod različitim režimima poljoprivredne obrade. Sveukupnu površinu valja rekonstruirati na temelju dobivenih podataka, što vrlo često nije moguće. Primijenit ćemo, stoga, vrlo robusnu tipologiju prema kojoj nalazišta razvrstavamo u samo dvije skupine oslanjajući se prije svega na veličinu, a potom i na gustoću i raznovrsnost površinskih nalaza.

Prvoj skupini ili tipu A pripadaju veće koncentracije površinskih nalaza koje najčešće indiciraju naseobinsko-gospodarsku funkciju te bi se mogle okvirno opredijeliti u vile rustike 3 . Dobar je primjer nalazište Makale 3, dokumentirano nakon svježega uništenja izoravanjem 2007. godine (Prilog 1: 10). Tom su prilikom na površini bile vidljive mrlje gareži, komadi žbuke te kamen uporabljen u gradnji, a također je zabilježeno nešto vrlo grubih tessera te manji broj dijagnostičnih ulomaka lončarije. Površina zabilježene koncentracije nalaza iznosi oko 100 × 100 metara, što se vrlo dobro podudara s obrisima kvadratične strukture koji su vidljivi na zračnom snimku, a koji iznose oko 100 × 120 metara (Prilog 3: 10).

2 U ovom su radu obrađena samo antička nalazišta pronađena sustavnim terenskim pregledom. Prilikom istraživanja 2009. godine antički su nalazi također zabilježeni kod Dajle, južno od širega područja istraživanja (Čučković 2010a).

3 Problem je, doduše, neodređenost toga termina, koji se nalazi na razmeđu antičkih literarnih referenci i tehničkoga arheološkog termina. Vila rustika za arheologa najčešće jednostavno znači veće antičko gospodarstvo sa slabije razvijenim rezidencijalnim, tj. luksuznim dijelom, te uglavnom ponešto udaljeno od većih urbanih centara (usp. Matijašić 1988: 16, Dyson 2003: 23-24). Međutim, villa je vrlo slabo zastupljena u epigrafskim izvorima te se najčešće pronalazi u pravnim tekstovima ili u »agronomskoj literaturi« Katona, Varona, Kolumele ili Paladija, gdje se može pratiti evolucija značenja od poljoprivrednoga gospodarstava do klasične palače (Leveau et al. 1993: 46). Dodatan je problem heteroklitna narav arheoloških podataka; prisutnost tragova luksuznijih ili pak gospodarskih elemenata ovisi o stanju očuvanosti i istraženosti nalazišta. 

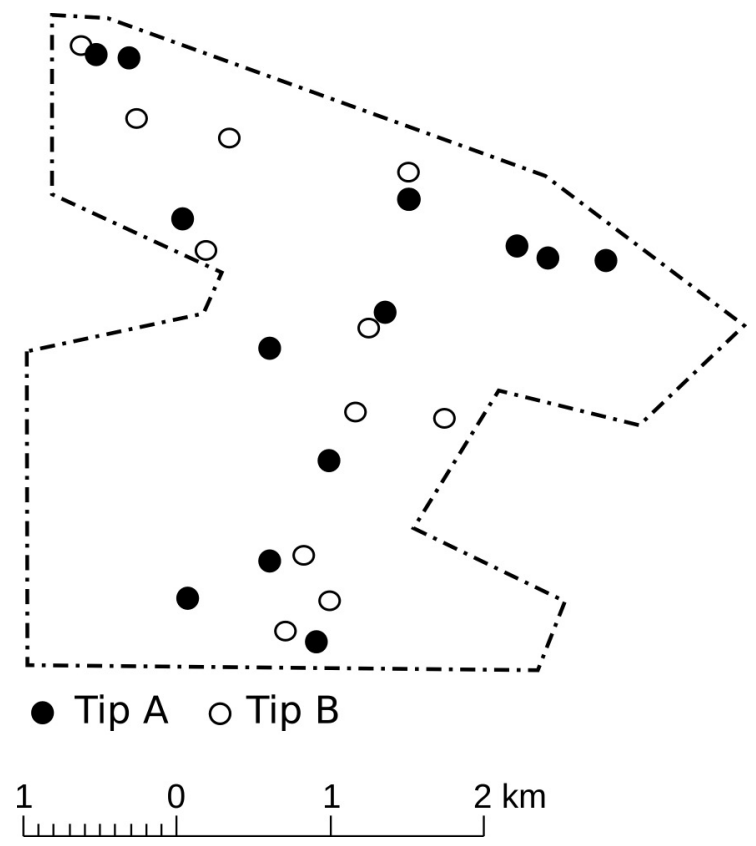

Sl. 4. Prostorni raspored dvaju osnovnih tipova dokumentiranih antičkih nalazišta

U blizini se nalazi nalazište Makale 1, također svježe razoreno prilikom sadnje maslinika (Prilog 1: 8). Za razliku od ostalih antičkih nalazišta, koncentraciju površinskih ostataka žbuke, kamena i sitnih nalaza je moguće donekle omeđiti. Sitni su nalazi razmjerno dobro uočljivi, a pronađen je i jedan primjerak rimskoga novca (nije obrađeno). Geofizičkim istraživanjem potvrđeno je očuvanje tragova arhitekture ispod površine, iako nije jasno u kojem stanju očuvanosti (Skelac 2009, Prilog 3: sl. 7). U zaseoku Makale, nedaleko od nalazišta, zabilježen je mogući ulomak kamenoga utega (Prilog 3: sl. 8). Identični primjerci težine 3 i 50 rimskih libri pronađenu su u Krvavićima-Boškini u južnoj Istri (Čimin 2007: 134-135).

Kao osnovni kriterij za uvrštenje u ovu skupinu odabrana je veličina površinske koncentracije nalaza koja se na temelju više primjera može odrediti na barem 100 × 100 metara ili više. Sukladno iznesenim pretpostavkama o utjecaju formacijskih procesa na sastav skupa površinskih nalaza, prisutnost pojedinih vrsta artefakata nije razmotrena kao kriterij, osim u slučajevima nalazišta kojima nije moguće procijeniti površinu ili koja su nešto manja od navedene veličine. Sudeći po analogijama u puljskom ageru, gdje prosječne dimenzije arhitektonskoga sklopa ruralnih gospodarstava uglavnom variraju oko 50 metara širine u kvadratičnom tlocrtu (Kolci: 60 × 50 m; Šijana 40 × 30 m; Šaraja 50 × 50 m; Matijašić 1982) te po obližnjoj vili rustiki iz Kršeta kod Buja, koja je 50 metara široka i 60 duga (Ujčić 2010), naše se dimenzije čine bitno različitima. Naime, pitanje je može li zemljoradnja udvostručiti površinu nalazišta, naročito kod svježe izoranih lokaliteta. Obrisi raspoznatljivi na zračnom snimku nalazišta Makale 3 također se čine nešto većima od spomenutih primjera (Prilog 3: 10). S druge strane nije jasan točan odnos površinskih koncentracija i ostataka arhitekture. Kada je riječ o sitnim artefaktima, svakako je moguće očekivati određene obrasce odbacivanja izvan naseljenoga prostora, kako je to zabilježeno na Hvaru (Bintilff et al. 1989: 51). Sljedeći je problem koncept antičkoga nalazišta koji 
je čvrsto vezan uz solidnu arhitekturu, naročito kod starijih iskopavanja, pa tek valja provjeriti mogućnost postojanja različitih aneksa rudimentarnoga karaktera u neposrednoj blizini građevine. Prema tome nije moguće sa sigurnošću zaključiti da su antička ruralna nalazišta u zaleđu Umaga u prosjeku značajno veća od onih u nekim drugim dijelovima Istre, prije nego što se razriješe spomenuti problemi.

Manja nalazišta pružaju znatno manje informacija te nije moguće izdvojiti naročito karakteristične primjere. Često se sastoje od usitnjenih ulomaka građevne keramike i rasutoga kamena te uglavnom ne sadrže površinske nalaze dijagnostičkoga tipa koji bi bili uočljivi primijenjenom metodom istraživanja. Pojedini detalji, kao na primjer veća količina zapečene zemlje na nalazištu Makale 2 (Prilog 1: 9), mogu upućivati na neku specifičnu uporabu, no bez pouzdanijih podataka razmatranje u tom smjeru nije moguće. Značajan su problem formacijski procesi kojima se mogu stvoriti površinske koncentracije koje nisu izravno povezane s izvornim obrascima odlaganja materijala (cf. supra) te često i datiranje isključivo na temelju usitnjenih ulomaka građevne keramike.

Budući da detalji o pojedinim primjercima malih nalazišta izostaju, moguće ih je razmatrati jedino skupno, tim više zbog određenoga stupnja nepouzdanosti prikupljenih podataka. Izravne analogije s prostora Istre zasad izostaju, iako su se u posljednje vrijeme, zahvaljujući manje permisivnoj politici u zaštiti kulturne baštine, počela intenzivnije istraživati manja agrarna antička nalazišta koja se ne mogu svrstati u skupinu vila rustika. Spomenimo nalazište u Maloj Šuridi kod Valbandona, gdje je pronađena manja građevina veličine $18 \times 13$ metara s dva tijeska za masline i popratnim radionicama (officinae). Vjerojatno je riječ o gospodarskoj građevini koja je pripadala većemu zemljoposjedu, latifundiji, sa središtem u okolici Fažane (Ujčić 2007). Kod Stancije Portun u blizini Poreča istraženo je jedno prilično »rustično« antičko nalazište koje je zanimljivo zbog veće količine čavala, na temelju čega istraživači pretpostavljaju značajnu konstrukciju u drvu (Kovačić i Brnić 2009). Međutim, na tom je nalazištu također pronađena znatnija količina ostaloga građevnog materijala (tegule i sl.), a i pretpostavljena veličina građevine ne odgovara tipičnomu malenom nalazištu. Također valja spomenuti ruralnu nastambu iz Labinaca veličine 15 × 15 metara, koja je, doduše, građena po shemi rimske vile rustike (Matijašić 1998: 302).

Navedeni istarski primjeri još uvijek ne izlaze iz okvira solidno zidane arhitekture. Kao primjer nalazištâ bez solidne gradnje, teško uhvatljivih ustaljenom strategijom arheološkoga iskopavanja antičkih lokaliteta, spomenimo istraživanja C. Raynauda i suradnikâ u Languedocu (Francuska) (Raynaud, Pomarèdes i Manniez 2009). Jedan je od ciljeva toga istraživanja bilo utvrđivanje karaktera »malih nalazišta« otkrivenih sustavnim terenskim pregledom. Najmanji su tip jednoprostorne strukture površine 30 do $50 \mathrm{~m}^{2}$, ponekad samo djelomično omeđene slabim zidom. Gradnja je ponekad izvedena samo u suhozidnoj tehnici, a nalazi su u pravilu vrlo siromašni (idem, 143). Slijede nešto veće strukture (oko 300 do 400 m²) u kojima nedostaje inventar kakav bi se očekivao u trajnijoj nastambi (ognjište, različiti tipovi lončarije itd.). Namjena je tih nalazišta nejasna, ponekad se označavaju kao »aneksi«, a mogla su biti privremeni zakloni za radnike ili za neke druge specifične djelatnosti. Veće ograđene strukture mogle su služiti sakupljanju stoke (ibid.).

Primijenjena je klasifikacija svakako vrlo rudimentarna. Problem koji zasad nije moguće razmotriti je postojanje nalazištâ koja nisu naseobinskoga karaktera, kao na primjer nekropola, prometnica i sl. Nalazi nadgrobnih spomenika kod Vilanije (Benedetti 1973: 26, Inscr. It. X, 3, 47) i Segeta (idem: 27, Inscr. It. X, 3, 49) te naročito vojničke diplome kod sela Jeci, koja vjerojatno potječe iz groba, zatim izvještaji o postojanju prometnice na tome mjestu, svakako upućuju i na 
postojanje takvih ostataka (Matijašić 1987: 83, Milotić 2009: 62). Međutim, kvaliteta prikupljenih podataka ne dozvoljava izlučivanje tih skupina nalazišta pa valja imati na umu da raspolažemo pojednostavljenim modelom antičkoga kulturnog krajolika. U makroperspektivi takve izolirane varijacije donekle gube na značaju, što je možda nagoviješteno razmjerno pravilnim rasporedom nalazišta te je stoga širi prostorni pristup najprimjereniji analizi dobivenih podataka.

\section{DATIRANJE}

Uslijed slaboga uzorka prikupljenih nalaza, barem kod većega dijela nalazišta, razlučivost datacije je vrlo slaba te u većini slučajeva površinska nalazišta određujemo tek u antičko razdoblje (1. do 6. st). Međutim, čini se da veća nalazišta u pravilu imaju nalaze iz razdoblja 1. do 4. st., dok su kasniji periodi rjeđe zastupljeni. Opća slika antičke Bujštine također pokazuje izrazitu dominaciju nalaza iz toga razdoblja, točnije iz 1. i 2. stoljeća, kao uostalom i veći dio zapadne Istre (Matijašić 1987: 93). Za razumijevanje procesa naseljavanja i romanizacije toga prostora značajna je nekropola u Kršetama kod Buja. Ondje je zabilježeno potpuno usvajanje rimskoga ritusa u 1. i početku 2. st., što je po R. Matijašiću jasan znak integriranosti u rimski kulturni krug (Matijašić 1997: 107).

Međutim, valja naglasiti da je karakteristika istarskih ruralnih naseobina također i kontinuitet kroz kasnu antiku, iako svakako sa značajnim transformacijama (usp. Dragonera: Starac 2010: 19; Stancija Pelićeti: Džin 2007: 257). Trend nagloga osnivanja brojnih gospodarstava tijekom 1. i 2. stoljeća te potom postupne transformacije većih naseobina kroz kasnu antiku dobro je dokumentiran u južnoj Istri (Matijašić 1982: 63). Bez detaljnije analize lončarije takav razvoj zasad nije moguće razlučiti iz materijala prikupljenoga terenskim pregledom Bujštine, no mjestimično pojavljivanje tipičnih ulomaka kasnoantičke lončarije narebrenih stijenki, uočeno tijekom pregleda, svakako upućuje na tu mogućnost. Dulje razdoblje uporabe pretpostvalja Š. Mlakar za nalazište kod Makala (vjerojatno naše nalazište Petrovija 8: Mlakar 1979: 37). Prema tome, moguće je pretpostaviti stvaranje naseobinskoga obrasca u zapadnoj Bujštini tijekom 1. i 2. stoljeća te vjerojatnu istovremenost većega dijela pronađenih nalazišta do 3. ili 4. stoljeća, a možda i dulje.

\section{PROSTORNA ANALIZA}

U svrhu detaljnije analize prostornih međuodnosa pronađenih nalazišta potrebno je odabrati područje s relativno pouzdanim podacima, a koje veličinom omogućuje promatranje širih naseobinskih obrazaca. Te zahtjeve zadovoljava jedino najveći blok istraženoga terena u zaleđu Umaga, iako tek donekle, budući da veličina od 4 × 4,5 km omogućava razmatranje na vrlo suženoj, lokalnoj razini. Šira regionalna analiza na temelju postojećih podataka iz literature izlazi iz okvira ovoga rada, a takav je pristup već primijenio S. Poglajen na području slovenske Istre i Bujštine (op. cit.).

\section{1) Raspored nalazišta}

Prostorni raspored dokumentiranih nalazišta promatramo na dvije razine: međuodnos dvaju naseobinskih tipova, u skladu s iznesenom klasifikacijom, te sveukupni raspored u prostoru. Znatan stupanj prostorne korelacije dvaju spomenutih tipova nalazišta vidljiv je već prilikom kartiranja (sl. 4), što se može i statistički provjeriti. Jednostavan je pristup pomoću podjele prostora u kvadratnu mrežu te izračunavanje vjerojatnosti dobivanja očitanih vrijednosti po 
kvadratu $X^{2}$ (hi kvadrat) metodom (Orton 1980: 143 ff). Veličina kvadrata je postavljena na 350 metara te su za svaki od njih zabilježena četiri moguća podatka: prisutnost obaju tipova, samo po jednoga tipa ili prazno polje. Ishod analize pokazuje statistički značajnu korelaciju $(P<0,05)$ pa zaključujemo da ovakav raspored nije slučajna osobina skupa podataka (tab. 3). Valja, međutim, istaknuti da je metoda u dobroj mjeri ovisna o veličini i postavljanju mreže kvadrata, što se može promatrati kao način odabira uzorka (ibid.). Primijenjena veličina nije slučajan odabir, već se temelji na opažanju da se lokalna grupiranja nalazišta mogu dobro razlučiti u radijusu od oko 300 metara. Taj iznos također odgovara prosječnim udaljenostima nalazišta u najbližem susjedstvu (tab. 4), što je ujedno i dobra provjera rezultata prethodne statističke metode (Orton 1980: 146).

\begin{tabular}{|c|c|c|c|}
\hline \multirow{2}{*}{$\begin{array}{c}\text { Prisutnost tipova nalazišta u mreži } \\
\text { kvadrata od } 350 \times 350 \mathrm{~m}\end{array}$} & Da & Ne \\
\cline { 2 - 4 } & & 5 & 5 \\
\hline \multirow{3}{*}{ Prisutnost tipa B } & $\mathrm{Da}$ & 8 & 70 \\
\cline { 2 - 4 } & $\mathrm{Ne}$ & 18,3 \\
\hline$X^{2}$ & & $<.001$ \\
\hline
\end{tabular}

Tablica 3.

\begin{tabular}{|c|c|c|c|}
\hline $\begin{array}{c}\text { Tipovi u najbližem } \\
\text { susjedstvu }\end{array}$ & Broj opažanja & $\begin{array}{c}\text { Prosječna } \\
\text { udaljenost }\end{array}$ & St. dev. ( $)$ \\
\hline A i B & 18 & 250 & 150 \\
\hline A i A & 8 & 320 & 160 \\
\hline B i B & 1 & 580 & $/$ \\
\hline \multicolumn{2}{|r|}{ Sveukupni indeks najbližega susjeda (NNI) } \\
\hline
\end{tabular}

Tablica 4 .

Tendencija grupiranja malih i velikih nalazišta upućuje na mogućnost funkcionalnih ili hijerarhijskih odnosa te, posljedično, na vjerojatnu istovremenost određenoga broja nalazišta u takvom odnosu. To je svakako tek opća slika koju zasad nije moguće razraditi. Manja bi nalazišta u tom modelu predstavljala pomoćne objekte ili neke druge jedinice funkcionalno povezane uz veća nalazišta, što bi također moglo biti u vezi s vlasničkim odnosima. Stoga ćemo pri razmatranju mogućih teritorijalnih odnosa izostaviti manja nalazišta, odnosno utvrditi diskretne naseobinske sklopove od više prostorno bliskih jedinica.

Kartiranje nalazišta također iznosi na vidjelo jasno grupiranje u južnom dijelu istraženoga područja. Međutim, indeks najbližega susjeda je u našem slučaju razmjerno blizu nasumičnoj distribuciji pa tom analizom nije moguće detektirati spomenute karakteristike prostornoga 

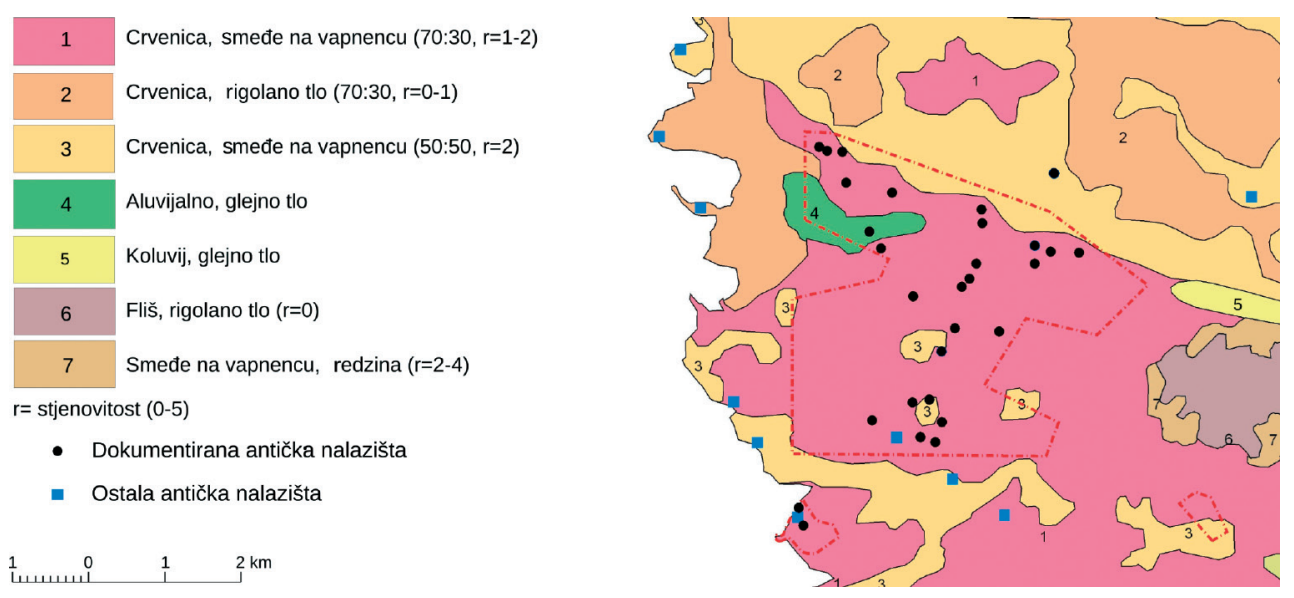

Sl. 5. Pedološka podloga (prema Škorić et al. 1983)

obrasca na razini istražene zone (tab. $4^{4}$ ). Čini se da su nalazišta raspoređena oko osi koja dijagonalno presijeca istraženi prostor, po svemu sudeći u smjeru luke i manje antičke naseobine u Sv. Ivanu. Pregled na području zapadno od Segeta i kod stancije Ambrozi u jugozapadnom i jugoistočnom uglu istražene zone nije dao mnogo rezultata pa pretpostavljamo manju koncentraciju nalazišta i na susjednom prostoru. S obzirom na malobrojnost otkrivenih nalazišta te na veličinu pregledane površine, taj obrazac zasad nije moguće podrobnije statistički analizirati. Distribucija nalazišta u sjevernom sektoru istražene zone povezana je uz neki drugi, zasad neraspoznatljiv obrazac koji nije moguće razlučiti bez proširenja zone istraživanja.

Sobzirom na nedvojbeno agrarnu narav otkrivenih nalazišta, svakako je uputno usporediti njihov raspored s pedološkom kartom (sl. 5). Međutim, izrazita homogenost pregledanoga krajolika, koji je gotovo u potpunosti prekriven dubokom do srednje dubokom crvenicom, ne omogućuje razmatranje preferenci u izboru naročite vrste zemljišta. Nešto varijabilnosti vidljivo je u topografiji, no u konačnici je ipak riječ o ravnom krajoliku, blago položenom prema obali, u kojem nema izrazitih topografskih prepreka. Prema tome, pretpostavljamo da su lokacijske datosti poput zemljišta, nagiba terena, vidljivosti, vegetacije itd. od značaja samo na mikronivou, tj. na razini pojedinoga nalazišta, dok je opći naseobinski obrazac uvjetovan drugim okolnostima, poput komunikacijske mreže, administrativne ili ekonomske organizacije i sl.

\section{2) Prometnice}

Moguće rješenje problema rasporeda nalazišta je u utjecaju lokalne komunikacijske mreže, naročito s obzirom na usmjerenost obrasca prema antičkoj luci u Sv. Ivanu, koja je posve sigurno imala određen lokalni značaj (Degrassi 1957: 53). Pretpostavljena prometnica koja bi povezivala luku u Sv. Ivanu i agrarno zaleđe nije dokumentirana u dostupnim nam povijesnim izvorima niti se može rekonstruirati na temelju postojeće cestovne mreže. Međutim, određene

4 Iznos indeksa najbližega susjeda (nearest neighbour index: NNI) upućuje na prirodu prostorne distribucije u odnosu na pretpostavljeni slučajni raspored. Negativne vrijednosti u rasponu od 0 do 1 upućuju na koncentrirani (grupirani) obrazac, a daljnje povećavanje (do najviše 2,15) na sustavnu raspoređenost u prostoru. Iznosi oko 1 su karakteristika nepravilnoga, tj. teoretski nasumičnoga rasporeda (Orton 1980: 188). 
naznake pronalazimo u topografskoj karti Istre Antonija de Capellarisa s kraja 18 st., koja se već pokazala kao vrijedan izvor podataka upravo u proučavanju antičkih prometnica (sl. 6, De Capellaris 1797, Gramaticopolo 2004).

Neobično je koliko sustav prometnica prikazan na Capellarijevoj karti odudara od današnjega stanja. Prikazane su prometnice ostatak ranije komunikacijske mreže venecijanske, odnosno srednjovjekovne Istre, ukoliko ne držimo da je problem u slaboj vjerodostojnosti karte. Naime, promatrajući određene pogreške na toj karti, kao npr. nepovezanost puta od Savudrije do Mlina kod Sečovlja s cestom prema Sečovlju (koja prolazi tim mjestom; sl. 6), jasno je da je dobar dio cestovne mreže iscrtan povezivanjem određenih mjesta prema poznatom itineraru, pa geografski položaj prometnica nije sasvim pouzdan.

Pretpostavljena antička prometnica prema Sv. Ivanu mogla bi se prikazati kao nastavak rute od Sečovlja do Vilanije, koja je potom skretala prema Umagu. Tijekom 19. st. ta je komunikacija potpuno izišla iz uporabe. Zanimljivo je da su fragmenti starijih prometnica dokumentirani našim terenskim pregledom između naselja Sv. Vid i crkvice Sv. Nikole te u podnožju Markovca, tj. upravo na toj ruti. U oba slučaja riječ je o slabo uređenim putovima koji su prepoznatljivi

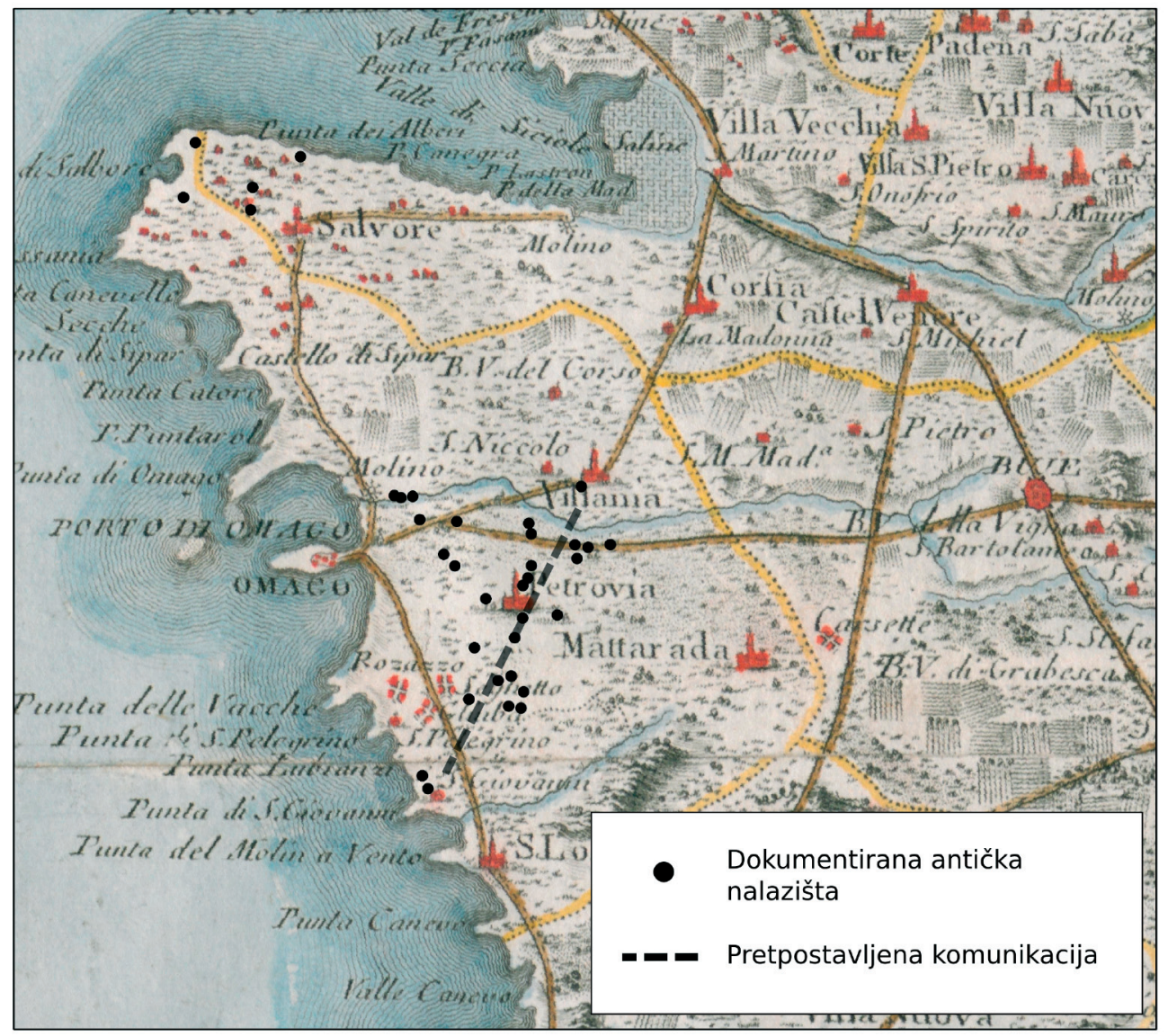

Sl. 6. Capellarisova topografska karta s približno pozicioniranim antičkim nalazištima dokumentiranima sustavnim terenskim pregledom (podloga: de Capellaris 1797) 
po kolotrazima od oko 100 - $120 \mathrm{~cm}$ širine. R. Matijašić donosi opis rimske prometnice kod Tornine, između Vilanije i Petrovije, što bi po položaju odgovaralo pretpostavljenomu nastavku antičke prometnice (Matijašić 1987: 83). Ta je lokacija također provjerena terenskim pregledom, no iako je riječ o poljskom putu koji zaista prolazi uz antički lokalitet, nismo u stanju utvrditi njegovu točnu dataciju bez daljnjega istraživanja.

Kako god bilo, pouzdani tragovi antičke prometnice zasad izostaju, a valja naglasiti da uz odsječak spomenute rute iz 18. st. koji prolazi pokraj Markovca nisu zabilježena značajnija antička nalazišta, iako je taj prostor već pregledan kako u sklopu terenskoga pregleda zapadne Bujštine, tako i prethodno izgradnji autoceste na tom mjestu (Komšo i Čuka 2009). Prema tome, topogafija prometnica s kraja 18. stoljeća ne može biti više od dodatne indikacije antičke mreže, i to tek u slučaju podudaranja s topografijom antičkih nalazišta.

\section{3) Problem veličine zemljoposjeda}

lako je u iznimnim slučajevima moguće rekonstruirati opseg pojednih antičkih zemljoposjeda na temelju epigrafskih ili drugih povijesnih vrela, a riječ je o onima najvišega ranga poput Lorona kod Poreča (Tassaux 2001: 322), podaci dobiveni topografskim istraživanjem ipak ostaju osnovni, ako ne i jedini donekle potpuni vodič u tom smjeru. Tim se pristupom vodio i R. Matijašić pri analizi antičkih agera Pule i Poreča (op. cit.).

Prethodno pokušaju analize valja se osvrnuti na određene metodološke i konceptualne probleme, prije svega na narav antičkoga zemljoposjeda i njegovo prepoznavanje arheološkom metodom. Mnoga su rimska imanja djelovala po zakupničkom sustavu, naročito u nešto kasnijim razdobljima rimske vlasti, pa prostorni kontinuitet zemljišta nije morao biti od neophodnoga značaja za njihovo održavanje. R. Matijašić naročito ističe da takav razvoj agrarnoga krajolika može proizvesti fragmentiran obrazac koji se može pomiješati sa sustavom malih imanja te se arheologija nalazi u značajnom problemu kod rekonstrukcije vlasničkih, tj. katastarskih odnosa na temelju arheološkoga materijala (Matijašić 1988: 98). To bi se svakako moglo odnositi na velike površine pod carskim fiskom koje su dobro dokumentirane u Istri (cf. supra). Takva su se zemljišta iznajmljivala ili usitnjavala i prodavala, a iz povijesnih je izvora poznata politika poticanja naseljavanja zapuštenih zemljišta krajem 2. stoljeća, što može biti širi kontekst vojničke diplome iz Jeca (Matijašić 1988: 99, Milotić 2009: 131).

Problem dijelom proizlazi iz postavljanja arheološke metode u kontekst historiografije. Arheološkim istraživanjem, pogotovo terenskim pregledom, na vidjelo izlaze tragovi ljudskoga djelovanja; obrada zemlje, podizanje naselja, odbacivanje otpada itd. Riječ je o perspektivi koja može biti ne samo nadopuna, već i suprotnost onoj koju nude povijesna vrela. Tragovi svakodnevnih aktivnosti stoje u izravnoj vezi s intenzitetom življenja na pojedinom području, a u tom su intenzitetu glavnu ulogu igrali niži slojevi društva, o kojima su povijesni izvori vrlo manjkavi. Promatrajući problematiku organizacije agrara s gledišta idealiziranoga senatorskog zemljoposjeda svakako ćemo se suočiti s neprimjerenošću arheoloških podataka. Vlasnik može biti arheološki vidljiv jedino u luksuznim zdanjima, koja mogu i ne moraju odgovarati središtima većih zemljoposjeda, te iznimno i u epigrafskim spomenicima. Ostatkom ruralnoga krajolika dominiraju jednostavna gospodarstva: vile rustike i manje farme, te tragovi utilitarnih predmeta: krhotine amfora i lončarije lokalne produkcije, tegule, imbreksi itd. Nepostojanje izravnih tragova koji bi kod takvih nalazišta omogućavali povezivanje s pretpostavljenim središtima veleposjeda otvara problem značaja katastarskih, tj. imovinskopravnih odnosa za razumijevanje nastanaka antičkoga ruralnog krajolika. To jest, koja je stvarna uloga velikih imanja u razvoju lokalnoga ruralnog krajolika? Naglasili bismo, dakle, da i sam koncept vlasništva, bez gradacije u smislu stvarnoga suvereniteta, može biti prilično problematičan, što je već nagoviješteno 
intervencijama državne administracije od 2. stoljeća nadalje u poticanju naseljavanja na zapuštenom zemljištu (op. cit.). U konačnici istaknimo da iako modeli razvijeni isključivo na temelju arheoloških podataka predstavljaju znatno pojednostavljenu sliku antičkoga društva, time ne odudaraju nužno od historiografskoga pristupa. Najbolje je rješenje u njihovoj kombinaciji (ili dijalektici).

U svrhu analize pretpostavljenoga teritorijalnog modela primijenjena je klasična metoda Voronojeva dijagrama5. S obzirom na već izloženo o obrascima grupiranja nalazišta, za središnje su točke u dijagramu odabrana središta naseobinskih jezgri u krugu od oko 300 metara, u kojima se u pravilu nalazi jedno ili rjeđe dva nalazišta tipa A. Metoda Voronojeva dijagrama počiva na nizu pretpostavki. Nalazišta, tj. naseobinske jezgre, moraju biti istovremena, naseobinski je obrazac znatno uvjetovan principom udaljenosti, jedinice unutar izabranoga skupa naseobinskih jezgri su ravnopravne, a ostali vanjski čimbenici poput heterogenosti okoliša, prirodnih prepreka i sl. su od zanemariva značaja. Iznesene pretpostavke očito ne mogu u potpunosti odgovarati antičkomu naseobinskom obrascu. Međutim, iako metoda Voronojeva dijagrama predstavlja znatno idealiziran pristup, ona ipak pruža određeni metodološki okvir kroz koji je moguće analizirati arheološke distribucije te, posredno, razmatrati i složenije aspekte društvene organizacije. Jednostavnost primjene ove metode također otvara mogućnost uspo-

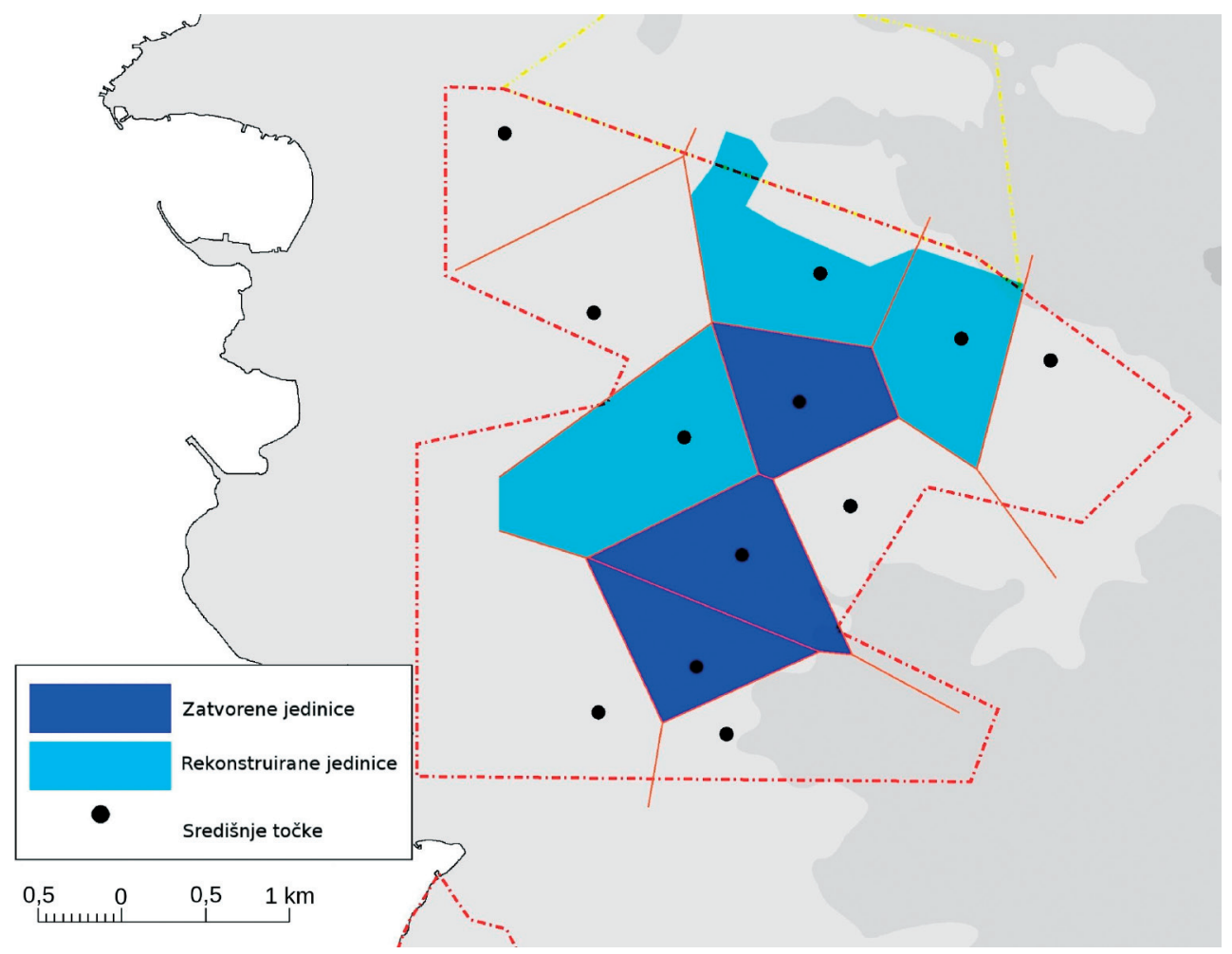

Sl. 7. Voronojev dijagram na temelju izlučenih naseobinskih jezgri

5 U Voronojevu ili Thiessenovu dijagramu svaka je jedinica u prostoru (točka, događaj) okružena ćelijom koja obuhvaća sve točke u prostoru koje su bliže toj jednici negoli nekoj drugoj. Razgraničenja se utvrđuju povlačenjem okomitih linija na polovici udaljenosti između svih obližnjih parova točaka (Orton 1980: 192). 
redbe arheoloških distribucija s ostatkom Istre iako je u tom smislu temeljni problem kvaliteta podataka dobivenih ekstenzivnim i nesustavnim pristupom.

U analizu dokumentiranoga prostornog obrasca moguće je uvrstiti samo šest ćelija, što je premalen broj za složenije razmatranje. Tri među njima su zatvorene, dvije smo rekonstruirali prema geološkoj razdjelnici kraškoga terena i pojasa crvenice na sjeveru, dok je jedna arbitrarno zatvorena na užem dijelu. Prosječna je površina ćelija oko 80 ha odnosno 320 iugera, što je manje od procijenjene prosječne veličine u južnom dijelu Istre (cf. supra). Razlika je tim izraženija što je sjeverniji dio Istre vjerojatno bio nešto slabije napučen od puljskoga agera, barem s obzirom na nedostatak kolonizacijskoga vala usporedivog s naseljavanjem kolonijskih agera u južnoj Istri te na pretpostavljenu dominaciju velikih agrarnih posjeda (Matijašić 1987: 92).

Uvažavajući navedene probleme primijenjene metode, tj. visok stupanj poopćavanja inače znatno složenijih društvenih i gospodarskih odnosa u antici, dobiveni se iznosi ne mogu izravno povezati s prosječnim veličinama zemljoposjeda. Dodajmo još i probleme terenskoga pregleda: vrlo grubu tipologiju nalazištâ i problem reprezentativnosti istraženoga uzorka krajolika. S druge strane, unatoč nejasnomu odnosu prema katastarskim i ostalim pravnim i društvenim odnosima, dobivene vrijednosti ipak odgovaraju određenomu intenzitetu naseljavanja, što se kroz buduće analize može povezati sa složenijim aspektima društvene i gospodarske organizacije. Sljedeći je korak integriranje ostalih arheoloških podataka u tako razvijene modele, kao npr. kod sličnoga pokušaja primjene Voronojeva dijagrama za područje sjeverozapadne Poreštine, gdje je u obzir uzeto više tipova nalazišta, nekropole i epigrafski spomenici (Tassaux 2012).

\section{4) Nalazi izvan nalazišta}

Podrobnija rasprava o problemu nalazâ izvan nalazišta izložena je u radu u pripremi (Čučković u tisku). Uz razmatranje povezanosti metodologije i kvalitete dobivenih podataka, što je izražen problem u kontekstu arheologije izvan nalazišta, na tom je mjestu ponuđena okvirna interpretacija načina nastanka dokumentiranih distribucija. S obzirom na rascjepkanost istraženih površina obrasci u prostornom rasporedu nalaza zasad su nejasni (sl. 8) te je kao ishodišni podatak pouzdanije razmotriti sveukupni sastav materijala prikupljenoga na otvorenom. Na sl. 9 vidljivo je podudaranje antičkoga i novovjekovnoga razdoblja u omjerima lončarije i građevne keramike te dominiranje ovoga posljednjeg materijala u oba slučaja. Na temelju toga se može zaključiti da uobičajeno tumačenje u smislu gnojidbe polja otpacima iz domaćinstva nije u potpunosti primjereno, budući da bi se u tom slučaju mogao očekivati veći udio lončarije (Mattingly 2000: 9). Predlažemo model u kojem, bez isključivanja gnojidbe, značajniju ulogu imaju drugačije agrarne aktivnosti, kao što je nasipanje putova i kasnije čišćenje poljâ te svakako i uništena, neprepoznatljiva nalazišta.

\section{ZAKLJUČAK}

Kroz proteklih pola stoljeća sustavni terenski pregled na Mediteranu pokazao se najuspješnijim u proučavanju antičkoga ruralnog krajolika. Razlog je prije svega u iznimnoj količini arheološkoga materijala te $u$ interesu istraživačâ za to razdoblje, ali i u naglom zamahu recentnih poljoprivrednih zahvata kojima je taj arheološki zapis iznesen na površinu. Danas su podaci dobiveni tom metodom osnova velikoga broja razmatranjâ antičkoga razdoblja u regionalnoj perspektivi, naročito kod tematike ruralnoga razvoja, dinamike naseljavanja i demografije.

U ovom je radu predstavljena preliminarna faza jednoga potencijalno dugotrajnog istraživanja te se suzdržavamo od donošenja konačnih zaključaka, iako su osnovne karakteristike antičkoga 


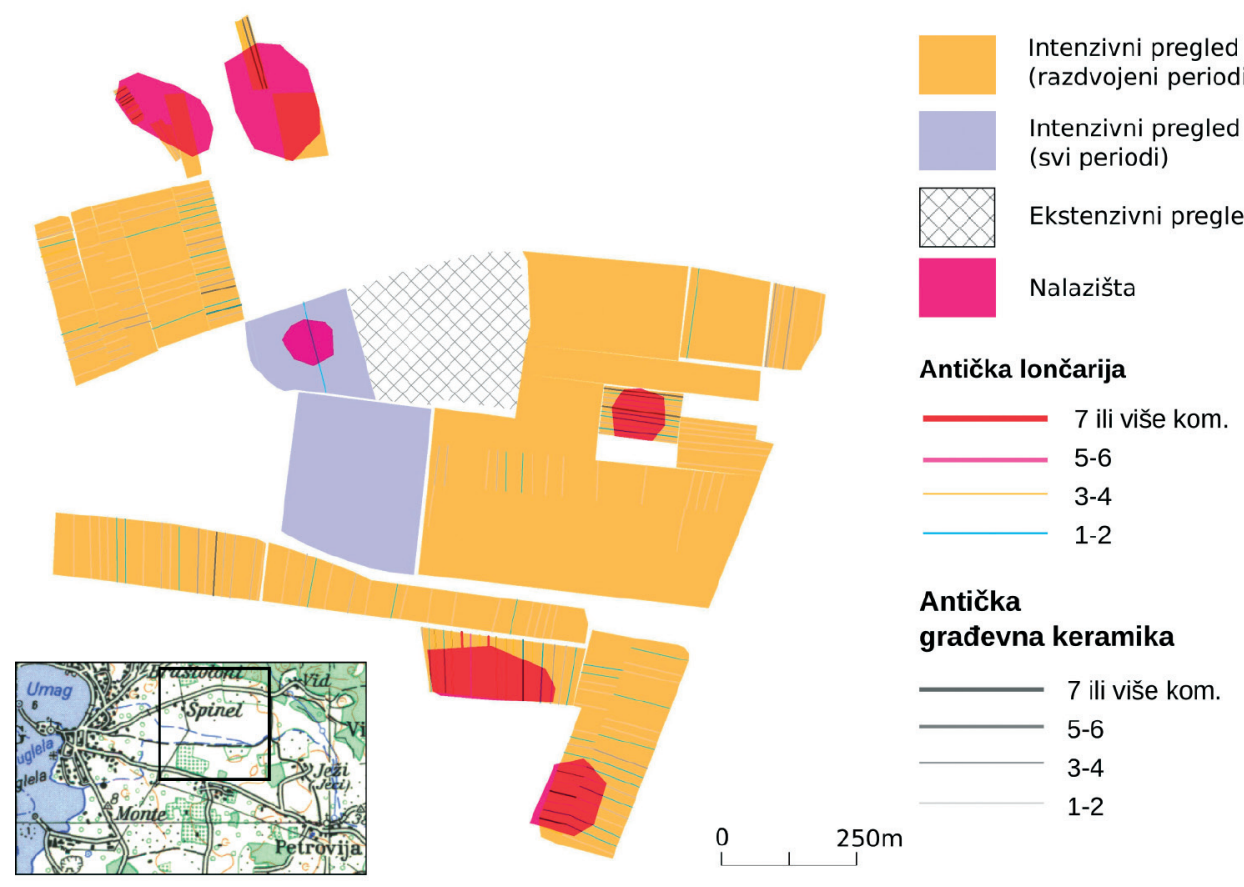

SI. 8. Koncentracije antičkih nalaza na području Špinela kod Umaga

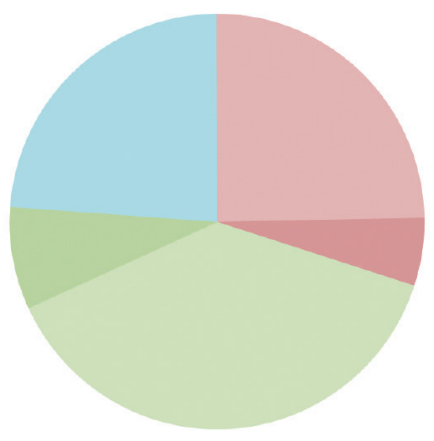

Građ. keramika:
antika
Lončarija: antika
Građ. keramika: novi
vijek
Lončarija: novi vijek
Ostali nalazi

Sl. 9. Udjeli osnovnih tipova površinskih nalaza prikupljenih prilikom sustavnoga terenskog pregleda 2008. godine

ruralnog krajolika svakako već očite. Želja nam je, prije svega, naglasiti potencijal metodološki i analitički integriranoga pristupa. Razmatranjem kvalitete dobivenih podataka kroz analizu utjecaja formacijskih procesa i primijenjene metodologije pokušali smo stvoriti osnovu za primjenu geostatističkoga pristupa. Činjenica je da je takve utjecaje vrlo teško kvantitativno izraziti s obzirom na iznimnu složenost povijesnoga razvoja kulturnoga krajolika, no bez uvažavanja tih »vanjskih«, tj. 
postdepozicijiskih čimbenika nije moguće utemeljiti bilo kakvu prostornu analizu. Dokumentirana arheološka nalazišta razvrstana su u tek dvije skupine, imajući u vidu slabu kvalitetu dobivenih podataka, ali i nedostatak detaljne analize materijala. Naročito valja istaknuti »mala nalazišta«, tip B, iako zasad nedostaju podrobniji podaci za njihovo razmatranje. Riječ je o vrsti arheološkoga lokaliteta koji se pokazao gotovo nevidljiv ustaljenim pristupom arheološkoga iskopavanja u Istri, prije svega zbog izostanka solidne arhitekture, a vjerojatno i složenijega stratigrafskog zapisa. Geofizičko snimanje na nekoliko odabranih nalazišta tipa A, iako tek pokusne naravi, pokazalo je razmjerno očuvane ostatke arhitekture te se čini idealnom nadopunom terenskoga pregleda u okviru širega nedestruktivnog pristupa.

Prostornom analizom dokazana je korelacija između dvaju tipova nalazištâ, čime je omogućeno dovođenje nalazištâ tipa B u širi kontekst antičkoga ruralnog krajolika, iako tek na poopćenoj razini. Distribuciju nalazišta interpretirali smo u svjetlu utjecaja jedne lokalne komunikacije, no naglasimo da je cestovnu mrežu moguće podrobnije istražiti tek u širem regionalnom kontekstu (npr. sjeverne Istre). Iskušana je i analiza naseobinskoga obrasca pomoću Voronojevih poligona, pristupa razmjerno čestog u arheologiji, i jednako toliko problematičnoga. Rezultat te metode treba shvatiti u kontekstu modela koji je impliciran, no u tome se ne razlikuje od bilo kojega drugog pristupa zasnovanog na jedoobraznoj metodologiji. Valja težiti »kumulativnoj vjerodostojnosti«, kako to naglašava J. Bintliff (2000: 214, n. 6; cumulative credibility), u kombinaciji terenskoga pregleda, iskopavanja i historiografskoga razmatranja, kako bi se dokučila složena pitanja društvene organizacije antičkoga krajolika.

U konačnici istaknimo i sustavno dokumentiranje nalaza izvan nalazišta, tzv. off-site arheologiju. Riječ je o jedinstvenom doprinosu sustavnoga terenskog pregleda kao metode usmjerene na proučavanja kulturnoga krajolika u kojoj je artefakt temeljna analitička jedinica. lako su prostorni odnosi sustavno dokumentiranih artefakata u krajoliku Bujštine zasad nejasni, na temelju prikupljenih podataka određene su tendencije ipak vidljive, prije svega u brojčanim odnosima lončarije i građevne keramike. Predložen je model koji uključuje širi spektar aktivnosti, a u kojem gnojidba polja, inače klasična interpretacija takvih nalaza (Bintliff 2000: 209), ne igra glavnu ulogu.

Sustavni se terenski pregled kroz proteklih pola stoljeća ustalio kao standradna arheološka metoda, no njegova je primjena još uvijek razmjerno neuobičajena u proučavanju arheološkoga krajolika. U ovom je radu predstavljen analitički potencijal podataka dobivenih tim pristupom, a naročit je naglasak postavljen na metodološke probleme. Nadamo se da ova studija, iako nije bez mana, pruža širi pregled složene povezanosti sustavnoga terenskog pregleda kao metode i prostorne arheologije kao istraživačkoga pristupa.

\section{Zahvala}

Zahvaljujem prof. Robertu Matijašiću na korisnim sugestijama. Sve moguće pogreške svakako zadržavam. 


\section{PRILOG 1: KATALOG ANTIČKIH NALAZIŠTA}

\section{KAMPANJA 2007}

\section{Bašanija 1}

Lokacija: Bašanija 4

Dokumentirana površina: 0,6 ha

Najviša koncentracija nalaza: 5 kom/min

Datacija: antika (?)

Opis: Vrlo slaba koncentracija građevinske keramike, nekoliko ulomaka lončarije antičke fakture. Nema kamena, a u iskopanim rupama za sadnju maslina nisu uočeni kulturni slojevi. Nepouzdano.

X: 5383261; Y: 5039399

\section{Borozija 2}

Lokacija: Borozija-2 2

Dokumentirana površina: 0,4 ha

Procijenjena površina: 1,1 ha

Najviša koncentracija nalaza: 13 kom/min

Datacija: antika, novi vijek

Opis: Značajnija koncentracija gotovo isključivo građevinske keramike. Faktura je jarkocrvena s malo nečistoća. Na jednoj je poziciji pronađen završetak dna amfore. Po pričanju mještana ovdje se nalazio dugačak zid koji se pružao okomito na cestu.

X: 5383608; Y: 5040226

Ilustracija: Prilog 3, SI. 1

\section{Frančeskija 1}

Lokacija: Frančeskija 4

Dokumentirana površina: 0,5 ha

Najviša koncentracija nalaza: 8 kom/min

Datacija: antika

Opis: Isključivo antička građevinska keramika; uočena tri ulomka tegula i amorfni ulomci. Gustoća nalaza je nešto veća na jugu i zapadu polja. Moguće manje antičko nalazište ili rubna zona lokaliteta koji se nalazi više prema jugu i zapadu.

X: 5384414; Y: 5039362

Ilustracija: Prilog 3, SI. 2

\section{Frančeskija 2}

Lokacija: Frančeskija 7

Dokumentirana površina: 0,4 ha

Najviša koncentracija nalaza: 10 kom/min

Datacija: antika

Opis: Maleno polje okruženo zapuštenim terenom, na kojem je pronađena uglavnom antička građevinska keramika i nešto lončarije antičke fakture. Vjerojatno rubni dio lokaliteta koji se prostire više na sjever. Kod stancije Frančeskija je pronađen nadgrobni natpis Kvinta Ragonija (1. - 2. st) (Benedetti 1973, 26; Inscr.It. X. 3, 42)

X: 5384325; Y: 5039002

Ilustracija: Prilog 3, SI. 2

\section{Jeci 1a}

Lokacija: Jeci 16

Dokumentirana površina: 0,6 ha

Najviša koncentracija nalaza: 14 kom/min

Datacija: antika i novi vijek

Opis: Rubni dio antičkog lokaliteta koji se prostire na susjednoj, zapadnoj čestici. Pronađeni su fragmenti lončarije antičke fakture, građevinska keramika i jedan fragment novovjekovne lule. Najveća koncentracija je zabilježena uz sjeverozapadni dio lokacije, a prilkom pregleda 2008 godine na lokaciji Jeci II 13, 130 metara sjeverno, je također pronađeno nešto malo antičke lončarije te bi ondje mogao biti krajnji doseg nalazišta. Pronađeni su fragmenti lončarije antičke fakture, građevna keramika i jedan fragment novovjekovne lule. X: $5388069 ;$ Y: 5032946 Ilustracija: Prilog 3, SI. 3

\section{Jeci 2}

Lokacija: Jeci 5

Dokumentirana površina: 0,3 ha

Najviša koncentracija nalaza: 6 kom/min

Datacija: antika, srednji vijek, novi vijek

Opis: Lokacija sa slabijom, ujednačenom koncentracijom lončarije iz različitih razdoblja, ponajviše antike, zatim srednjeg i novog vijeka. Pregledana lokacije je vrlo mala, pa je moguće da se radi o rubnom dijelu nekog većeg nalazišta. Nepouzdano.

X: 5387966; Y: 5032509

\section{Jeci 3}

Lokacija: Jeci 3-8

Dokumentirana površina: 0,8 ha

Najviša koncentracija nalaza: 20 kom/min Datacija: prapovijest (?), antika, novi vijek Opis: Veće antičko nalazište na blagoj uzvisini pokraj ceste između sela Petrovija i Jeci (Ježi), 130 m od lijeve obale Potoka. Osim ulomaka rimske lončarije pronađeni su i lomci grube, porozne fakture, moguće prapovijesne datacije X: 5387876; Y: 5032317 Ilustracija: Prilog 3, SI. 9

\section{Makale 1}

Lokacija: Makale 18

Dokumentirana površina: 0,8 ha

Procijenjena površina: 1,3 ha

Najviša koncentracija nalaza: 100 kom/min

Datacija: antika

Opis: Nalazište oko 150 m južno od zaseoka Makale poznato je među stanovništvom kao Ciglana. Prilikom terenskog pregleda pronađeno 
je mnogo građevinske keramike, lončarija i jedna kovanica. Vjerojatno je razlog tome nedavno duboko oranje radi sadnje maslinika, no georadaskim snimanjem na površini od $32 \times 20$ m je ipak utvrđeno postojanje podpovršinskih struktura. Makale su odranije poznat antički lokalitet, no nemamo podatke o točnoj pozicija nalazišta što je problem zbog gustoće antičkih ostataka na tom mjestu (Matijašić 1987, 84: s.v. Makale II).

X: 5387132; Y: 5030730

Ilustracija: Prilog 3, SI. 6-8

\section{Makale 2}

Lokacija: Makale 21

Dokumentirana površina: 0,5 ha

Najviša koncentracija nalaza: 56 kom/min

Datacija: antika

Opis: Pronađen je rubni dio nalazišta na obronku brežuljka iznad Makala. Najveća koncentracija nalaza nalazi se uz istočni rub polja na koje se dalje nastavlja gusto grmlje i šuma. Pronađeno je dosta ljepa i tragova paljevine (taljevina?), te fragmenti rimske lončarije.

X: 5387354; Y: 5030768

Ilustracija: Prilog 3, SI. 6

\section{Makale 3}

Lokacija: Makale 31

Dokumentirana površina: 1 ha

Procijenjena površina: 1,1 ha

Najviša koncentracija nalaza: 29 kom/min

Datacija: antika

Opis: Nalazište rimskog objekta čiji se dijelovi uništavaju oranjem. Prilikom pregleda pronađeni su krupniji ulomci žbuke, moguće od podova, te dosta građevinske keramike i nešto lončarije, uglavnom ulomaka posuda većeg promjera. Površina na kojoj se rasprostire povišena gustoća sitnih nalaza razmjerno je jasno omeđena, što govori u prilog manjem stupnju devastacije poljoprivrednim radovima. Georadarsko snimanje je provedeno u sondi od tek desetak metara širine, usljed nedostupnosti oranice na kojoj se nalazi središte nalazišta. Utvrđene su anomalije ispod površine, no određena struktura zasada nije raspoznatljiva (Skelac 2009).

X: 5387430; Y: 5030222

Ilustracija: Prilog 3, SI. 10

\section{Makale 4}

Lokacija: Makale 34

Dokumentirana površina: 0,1 ha

Najviša koncentracija nalaza: 6 kom/min

Datacija: antika

Opis: Manje antičko nalazište 170 m zapadno od nalazišta Makale 31. Pronađeni su samo amorfni ulomci antičke fakture u vrlo slaboj koncentraciji od 3 - 7 kom $/ \mathrm{min}$. Nalazište se vjerojatno širi na sjever.

X: 5387237; Y: 5030284

Ilustracija: Prilog 3, SI. 10

\section{Makale 5}

Lokacija: Makale 25

Dokumentirana površina: 1 ha

Procijenjena površina: 1 ha

Najviša koncentracija nalaza: $18 \mathrm{kom} / \mathrm{min}$

Datacija: antika

Opis: Slabija koncentracija antičke građevinske keramike i lončarije na lokaciji $550 \mathrm{~m}$ istočno od Spekule i 600 m jugoistočno od Makala. Uz južni rub polja, na kojem je izmjerena i najveća gustoća nalaza, zabilježena je nakupina krupnijeg kamena, 5 metara u promjeru.

X: 5387514; Y: 5030481

Ilustracija: Prilog 3, SI. 11

\section{Materada 2}

Lokacija: Materada 2

Dokumentirana površina: 0,2 ha

Najviša koncentracija nalaza: $6 \mathrm{kom} / \mathrm{min}$

Datacija: kasna antika (?)

Opis: Vrlo slaba koncentracija nalaza antičke lončarije te nešto ulomaka debele, porozne fakture, moguće kasnoantičke ili ranosrednjovjekovne datacije. Lokacija se nalazi u podnožju brežuljka Karovlje koji ima širok, zaravnjen plato na vrhu, obrubljen nasipom od 2 m visine. Na Karovlju nije pronađena značajnija količina arheoloških nalaza. Nepouzdano.

X: 5391023; Y: 5029276-

\section{Petrovija 1}

Lokacija: Jeci 12

Dokumentirana površina: 2 ha

Najviša koncentracija nalaza: 12 kom/min

Datacija: antika, srednji vijek, novi vijek

Opis: Oranica, na površini je vidljivo kamenje

dimenzija $30 \times 40 \mathrm{~cm}$, koje se od istočnog ruba (uz cestu) nastavlja dalje u dužini od $50 \mathrm{~m}$. Pronađeni su nalazi relativno slabe gustoće, većinom antičke fakture, a prikupljen je i jedan grubi ulomak izrađen na kolu (srednji ili novi vijek) te ulomci novovjekovne lončarije. Nalazište se nalazi između dva antička lokaliteta, Jeci 3 i Petrovija 27.

X: 5387776; Y: 5032210

Ilustracija: Prilog 3, SI. 9

\section{Petrovija 3}

Lokacija: Petrovija zap. 27-31

Dokumentirana površina: 1,4 ha

Procijenjena površina: 2,2 ha

Najviša koncentracija nalaza: $100 \mathrm{kom} / \mathrm{min}$

Datacija: antika 
Opis: Veći antički lokalitet koji se nalazi u blizini kuće obitelji Delben (Del Ben), na zapadnom kraju sela Petrovija. Pronađeno je mnogo fragmenata rimske građevinske keramike i lončarije, a sjeverozapadu pregledane površine zabilježeno je dosta nalaza recentne i novovjekovne glazirane keramike. Ovo je vjerojatno posljedica blizine starijih kuća uz cestu prema Umagu.

X: 5387141; Y: 5032090

Ilustracija: Prilog 3, SI. 12

\section{Petrovija 4}

Lokacija: Petrovija zap. 38-41

Dokumentirana površina: 0,6ha

Procijenjena površina: 0,9 ha

Najviša koncentracija nalaza: 25 kom/min

Datacija: antika

Opis: Slabija koncentracija antičkih nalaza, koja se proteže na manjoj površini unutar obrađenog voćnjaka na jugozapadnom rubu sela Petrovija.

Pronađeno je i nešto dijagnostičkog antičkog materijala; ručke i rubovi amfora.

X: 5387688; Y: 5031680

Ilustracija: Prilog 3, SI. 13

\section{Petrovija 5}

Lokacija: Petrovija ist. 16

Dokumentirana površina: 0,2 ha

Najviša koncentracija nalaza: 16 kom/min

Datacija: antika

Opis: Rubno područje antičkog nalazišta koje se širi prema istoku. Susjedna lokacija je u trenutku pregleda bila zarasla, pa nisu uočeni nalazi. Pronađeno je dosta pozdanih ulomaka lončarije rimske fakture.

$X: 5388261 ; Y: 5031639$

Ilustracija: Prilog 3, SI. 14

\section{Petrovija 6}

Lokacija: Petrovija-3 15

Dokumentirana površina:0,35 ha

Datacija: antika (?)

Opis: Vrlo visoka koncentracija smrvljene građevinske keramike (mještani spominju »ciglanu« na tom mjestu). Zabilježena je samo recentna lončarija iako se u blizini nalaze dva antička nalazišta.

Zasada nepouzdano.

X: 5388133; Y: 5031688

Ilustracija: Prilog 3, SI. 14

\section{Petrovija 8}

Lokacija: Petrovija zap. 10-11

Dokumentirana površina: 0,8 ha

Procijenjena površina: 0,8 ha

Najviša koncentracija nalaza: 30 kom/min
Datacija: antika

Opis: Antičko nalazište koje je pronađeno u zapuštenom vinogradu sa slabom vidljivošću tla (do 10\%). Ukoliko bismo u dobivene gustoće nalaza uračunali i vidljivost ovo bi bilo jedno od nalazišta sa vrlo velikom gustoćom površinskih artefakata. Vjerojatno se radi o nalazištu koje donose Matijašić $(1987,84)$ kao Makale I i Mlakar $(1979,35-37)$. X: 5387510; Y: 5031383

Ilustracija: Prilog 3, SI. 15

\section{Petrovija 10}

Lokacija: Petrovija-3 13

Dokumentirana površina: 0,2 ha

Datacija: antika

Opis: Slabija koncentracija antičke keramike. Nalazište je preplavljeno recentnim nalazima budući

da se nalazi u neposrednoj blizini naselja

X: 5388047; Y: 5031712

Ilustracija: Prilog 3, SI. 14

\section{Seget 3}

Lokacija: Makale 10

Dokumentirana površina: 2,7 ha

Procijenjena površina: 5,3 ha

Najviša koncentracija nalaza: 35 kom/min

Datacija: antika

Opis: Veliki antički lokalitet u blizini stancije

Seget, vjerojatno bitno uništen oranjem. Lokalitet je položen na blagu padinu, a mjesto najviše koncentracije artefakata stoji na vrlo blagom uzvišenju tako da je mogući uzrok većih koncentracija intenzivnije skidanje tla oranjem. Pronađeno je razmjerno malo ulomaka rimske lončarije. Georadarskim snimanjem na površini od 33 × $27 \mathrm{~m}$ su locirani tragovi arhitekture, moguće i jednog dublje ukopanog elementa (cisterna ?) (Skelac 2009). Kod stancije Seget je na tri stope dubine pronađen nadgropni natpis Lucija Pleksina (Benedetti 1973, 27, Inscr. It., X, 3, 49)

X: 5386608; Y: 5030500

Ilustracija: Prilog 3, SI. 4-5

\section{Sv. Ivan 3}

Lokacija: Sv Ivan 4-6

Dokumentirana površina: 1,5 ha

Procijenjena površina: 4,2 ha

Najviša koncentracija nalaza: 200 kom/min

Datacija: antika

Opis: Bogato antičko nalazište uz malenu luku u Sv. Ivanu poznato je još od sredine 19. st. (Degrassi 1957, 50). Najviša gustoća nalaza pronađena je upravo unutar rimske luke, na čestici stotinjak metara sjeverno od početka antičkog lukobrana. Pronađeno je mnogo fragmenata antičke lončarije i građevinske keramike, žbuka, nešto tessera i 
fragment stakla. Ima i vrlo grube, možda kasnoantičke lončarije. Na jugozapadnom dijelu nalazišta je 2009. godine istražen veći antički objekt s termalnim sklopom (Katunarić 2009).

X: 5385662; Y: 5029349

Ilustracija: Prilog 3, SI. 16

\section{Sv. Ivan 4}

Lokacija: Sv Ivan 8

Dokumentirana površina: 0,1 ha

Procijenjena površina: ha

Najviša koncentracija nalaza: 7 kom/min

Datacija: antika

Opis: Slabija koncentracija fragmenata antičke građevinske keramike, uz cestu koja se vjerojatno prati trasu antičke komunikacije. Zbog veličine pregledane površine nije moguće procjeniti opseg ili smjer širenja lokaliteta.

X: 5385711; Y: 5029155

\section{Valfontane 1}

Lokacija: Valfontane 8-9

Dokumentirana površina: 0,6 ha

Najviša koncentracija nalaza: $10 \mathrm{kom} / \mathrm{min}$

Datacija: antika

Opis: Na polju južno od srednjovjekovne crkvice Sv Lovre u Valfontani, 100m zapadno od kraške lokve, zabilježena je slabije izražena koncentracija antičke građevinske keramike. Gustoća se povećava prema čestici na kojoj se nalazi crkvica, pa je za očekivati da se u blizini crkvice nalazi antičko nalazište. 2007. godine su probnim sondiranjem oko crkve pronađeni zidovi antičkog objekta (Bekić et. al. 2008).

Ilustracija: Prilog 3, SI. 17

X: 5385244; Y: 5039734

\section{Vilanija 3}

Lokacija: Petrovija sjev. 45

Dokumentirana površina: 0,4 ha

Najviša koncentracija nalaza: $12 \mathrm{kom} / \mathrm{min}$

Datacija: antika

Opis: Slaba koncentracija antičke lončarije na više zemljišnih čestica uz cestu Petrovija- Vilanija, 1,4 km od Petrovije. Susjedna polja na koja se koncentracija širi nije bilo moguće pregledati. Vjerojatno rubni dijelovi većeg nalazišta.

X: 5388929; Y: 5032640

\section{KAMPANJA 2008}

\author{
Jeci $\mathbf{1 b}$ \\ Lokacija: Jec II. 14 \\ Dokumentirana površina: 0,2 ha \\ Najviša koncentracija nalaza: $9 \mathrm{kom} / \mathrm{min}$ \\ Datacija: antika \\ Opis: Rubni dio antičkog nalazišta koje se proteže \\ prema potoku na jugu. Koncentracija nalaza \\ opada u smjeru nalazišta Jeci 1a (pregled 2007.). \\ Osim ulomaka građevinske keramike i obične \\ lončarije ovdje je pronađen i ulomak terre sigillate. \\ Obale potoka su zarasle pa nije bilo moguće \\ provjeriti postojanje kulturnih slojeva. Nešto \\ nalaza je pronađeno i na susjednoj lokaciji (Jec II. \\ 13). \\ X: 5387863, Y: 5033045 \\ Ilustracija: Prilog 3, SI. 3
}

\section{Špinel 5 \\ Lokacija: Jeci II. 3 \\ Dokumentirana površina: 1,5 ha \\ Najviša koncentracija nalaza: 1,3kom/min \\ Datacija: antika, novi vijek (?) \\ Opis: Jedno dno amfore, nekoliko ulomaka antičke Iončarije i vrlo malo ulomaka građevinske kera- mike (jedan ulomak tegule). Ne prepoznaje se nikakva definirana koncentracija nalaza. Nalazište je vjerojatno znatno uništeno zemljoradnjom. X: 5386271 , Y: 5033543}

\section{Špinel 7}

Lokacija: Jeci II. 9

Dokumentirana površina: 0,7 ha

Najviša koncentracija nalaza: $1 \mathrm{kom} / \mathrm{min}$

Datacija: antika

Opis: Slabije antičko nalazište sa donekle omeđenom koncentracijom građevinske keramike i malo lončarije. Od lončarije je pronađeno nekoliko ulomaka amfora. Čini se da je ovo nalazište teže oštećeno pri poljoprivrednim radovima. X: 5386869, Y: 5033418

\section{Špinel 11}

Lokacija: Jeci II. 18B

Dokumentirana površina: 3 ha

Najviša koncentracija nalaza: 5,4 kom/min

Datacija: antika

Opis: Koncentracija antičkih nalaza. Osim građevinske keramike pronađeni su ulomci tipične lončarije te dijelovi amfora i dolija. Također je pronađen i fragment stakla. Koncentraciju nije moguće jasno omeđiti pa je za pretpostaviti da je lokalitet znatno oštećen poljoprivrednim radovima.

X: 5386571, Y: 5032919 


\section{Špinel 12}

Lokacija: Jeci II. 17 a

Dokumentirana površina: 2,6 ha

Najviša koncentracija nalaza: 8,4 kom/min

Datacija: antika, prapovijest(?)

Opis: Manji antički lokalitet, moguće u vezi sa nalazištem Špinel 11. Oba se ova nalazišta protežu prema zapadnoj padini uzvisine na kojoj su smješteni pa se može pretpostaviti postojanje još nalaza na prostoru koji nije pregledan. Osim slabije izražene koncentracije građevinske keramike, pronađeno je dosta ulomaka antičke lončarije. Među nalazima ima nešto ulomaka amfora, te ulomak uljanice.

X: 5386723, Y: 5032701

\section{Tornina (Vilanija 1)}

Datacija: antika

Opis: Arheološko nalazište poznato kao Tornina kod lokalnog stanovništva. Lokacija je zarasla u travu pa nije provedeno sustavno dokumentiranje. Vidljiva je veća količina antičke keramike (dosta dijagnostičkih komada) i tegula. Koncentracija je najveća uz sjeverni rub polja, a u susjednom, zapadnom polju u iskopima za masline nisu bili vidljivi nikakvi slojevi ili artefakti. Na polju sa sjeverne strane, prema kojemu se povećava koncentracija nalaza, na površinu izbija živa stijena, a cijelo je polje potpuno zaraslo. Ova se lokacija podudara sa opisom nalazišta vojničke diplome (Matijašić 1987, 83). Zanimljivo je i da lokalno stanovništo ovo nalaziše povezuje sa »grobljem«. Georadarski snimak na površini od 50 x 10 metara nije dao jasne rezultate (Skelac 2009). X: 5388544, Y: 5032477

\section{Ungarija 1}

Lokacija: Špinel 15

Dokumentirana površina: 0,7 ha

Najviša koncentracija nalaza: 37 kom/min

Datacija: antika

Opis: Značajnija koncentracija antičke keramike koja je popraćena i nešto sitnijim kamenom. Istočni dio lokacije je bio znatno slabije vidljiv, pa je vjerojatno da se koncentracija nalaza proteže preko čitavog polja. Pronađeno je više dijagnostičkih ulomaka lončarije, uglavnom tipične datacije razvijenog carstva, a jedan narebreni ulomak mogao bi datirati u 4. st ili kasnije.

X: 5386218, Y: 5033940

\section{Ungarija $\mathbf{3}$}

Lokacija: Špinel 13

Najviša koncentracija nalaza: 20 kom/min

Datacija: antika, novi vijek

Opis: Nalazište koje je najvjerojatnije vezano uz

Ungariju 4. Osim koncentracije građevinske kera- mike pronađeno je više ulomaka koji se mogu opredijeliti u razvijeno Carstvo, te jedan ulomak stakla.

X: 5385919, Y: 5034000

\section{Ungarija 4}

Lokacija: Špinel 11

Dokumentirana površina: 1 ha (s nalazištem Ungarija 3)

Najviša koncentracija nalaza: $20 \mathrm{kom} / \mathrm{min}$

Datacija: antika, srednji vijek (?), novi vijek

Opis: Veće nalazište sa tragovima iz više razdoblja. Čini se da je nalazište poprilično uništeno, tako da nije moguće omeđiti koncentracije nalaza. Većina pronađenih artefakata je iz doba antike te je ravnomjerno raspoređena po cijeloj lokaciji. Od nalaza lončarije karakteristični su ulomci sive boje i fakture sa sitnim pijeskom te fragmenti amfora. Pronađena građevinska keramika je uglavnom iz novijih razdoblja, što odudara od tipične situacije za ruralne antičke lokalitete. Pronađeno je i nekoliko komada vrlo porozne fakture kakvi su već zabilježeni kod Materade i u blizini Segeta za koje još ne znamo točnu dataciju (srednji vijek?). Ima i nekoliko komada koje zasada određujemo kao srednjovjekovne, te više ulomaka novovjekovne lonačarije. X: 5386021, Y: 5033956

\section{Vilanija 2}

Lokacija: Petrovija 5

Datacija: antika, novi vijek

Opis: Aničko nalazište uz stari poljski put. Moguće da se radi o »ostacima stare rimske ceste« koju spominje Matijašić $(1987,83)$ Uzduž puta pruža se gromača na kojoj se mogu pronaći ulomci antičke keramike, a na istočnom kraju puta, na mjestu gdje je izbrisan modernom parcelacijom nalazi se veća gomila kamena u koja sadrži veću količinu ulomaka antičke keramike. Tvorevina (put) se sastoji od dva paralelna udubljenja $20 \mathrm{~cm}$ dubine na razmaku od oko $70 \mathrm{~cm}$. Udubljenja su također široka oko $70 \mathrm{~cm}$ ili više. Na samome putu podignut je danas napušteni stambeni objekt građen tradicionalnom tehnikom (kamenom), pa se može zaključiti da je put izišao iz uprabe prije najmanje stotinjak godina. Položaj arheološkog lokaliteta južno od puta nije detaljno pregledan zbog zaraštenosti. X: 5388756, Y: 5032532

\section{Vilanija 4}

Lokacija: Vilanija III. 2

Dokumentirana površina: 2 ha

Procijenjena površina: 4 ha

Najviša koncentracija nalaza: 19 kom/min 
Datacija: antika, prapovijest

Opis: Veće antičko nalazište (koncentracija keramike na oko 2 ha). Nalazi su prilično fragmentirani, a pronađeno je nešto obične lončarije, te građevinske keramike. Najveća količina nalaza dolazi sa sjeverozapadne strane lokacije, pa je u tom smjeru za očekivati središte nalazišta.

Ilustracija: Prilog 3, SI. 18

X: 5389303, Y: 5032649

\section{EKSTENZIVNI PREGLED}

\section{Borozija 1}

Nalazište u neposrednoj blizini ulaza u kamp Borozija je ranije zabilježio R. Matijašić (1987, 78). Teren je zarastao pa detaljan pregled nije proveden. Uočeni su ostaci zidova uz pristupni put te dvije gromače visine do 1,5m u blizini. Također ima sitnih nalaza na žalu i u profilu obale, no u razmjerno slaboj koncentraciji.

\section{Sv. Nikola}

Odranije poznato antičko nalazište (Bradanović 2005) koje se nalazi izvan zone intenzivnog pregleda te nije detaljno obrađeno. Prilikom posjeta 2008. godine je zabilježen veći obrađeni kameni blok kvadarnog oblika $(115 \times 80 \mathrm{~cm})$ neposredno uz crkvu.

\section{Sv. Petar}

Značajno prapovijesno gradinsko naselje (BuršićMatijašić 2007, 433). Prilikom terenskog pregleda je pronađeno dosta ulomaka republikanske i/ili kasnohelenističke lončarije koji pripadaju kasnijim fazama prapovijesnog naselja. 


\section{PRILOG 2: KARTA NALAZIŠTA}

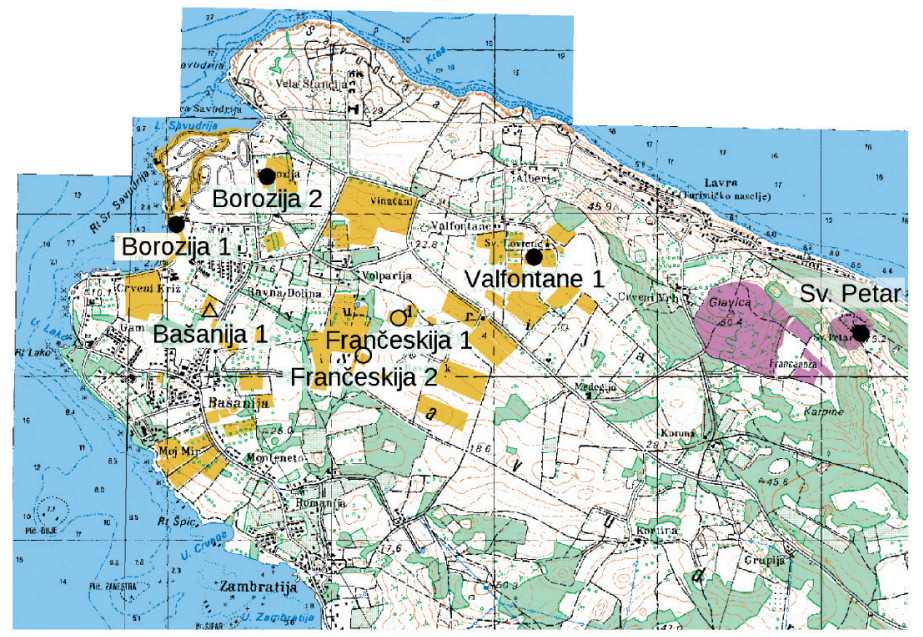

1) zaleđe Savudrije

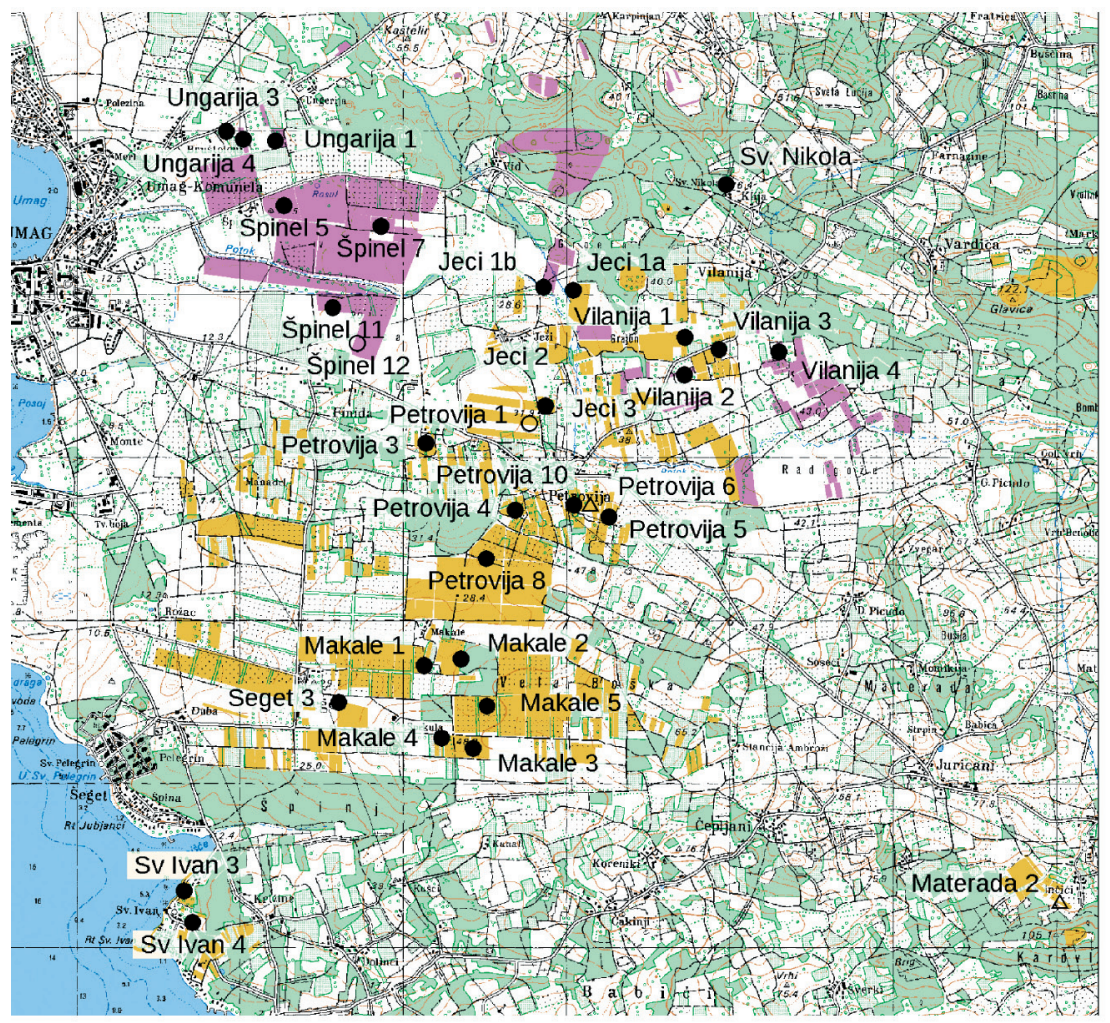

2) zaleđe Umaga

- Pouzdani nalazi

Vjerojatno nalazište

Pregled 2007.

$\triangle$ Nepouzdano 


\section{PRILOG 3: SLIKOVNA DOKUMENTACIJA ODABRANIH NALAZIŠTA}

\section{Legenda}

Broj nalaza u 1 minuti pregleda

Dokumentirana površina

Pretpostavljena površina

Geofizičke sonde

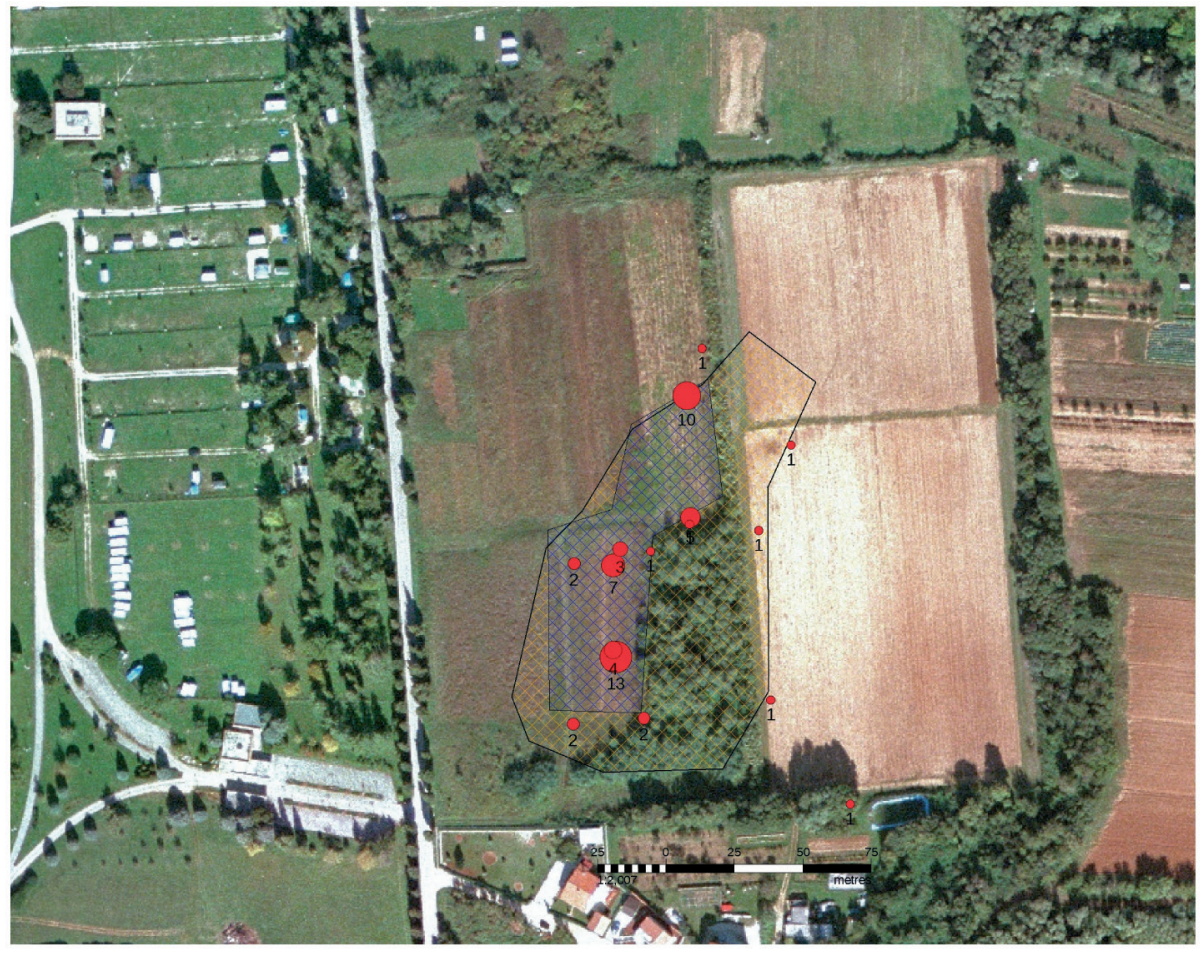

1) Borozija 2 


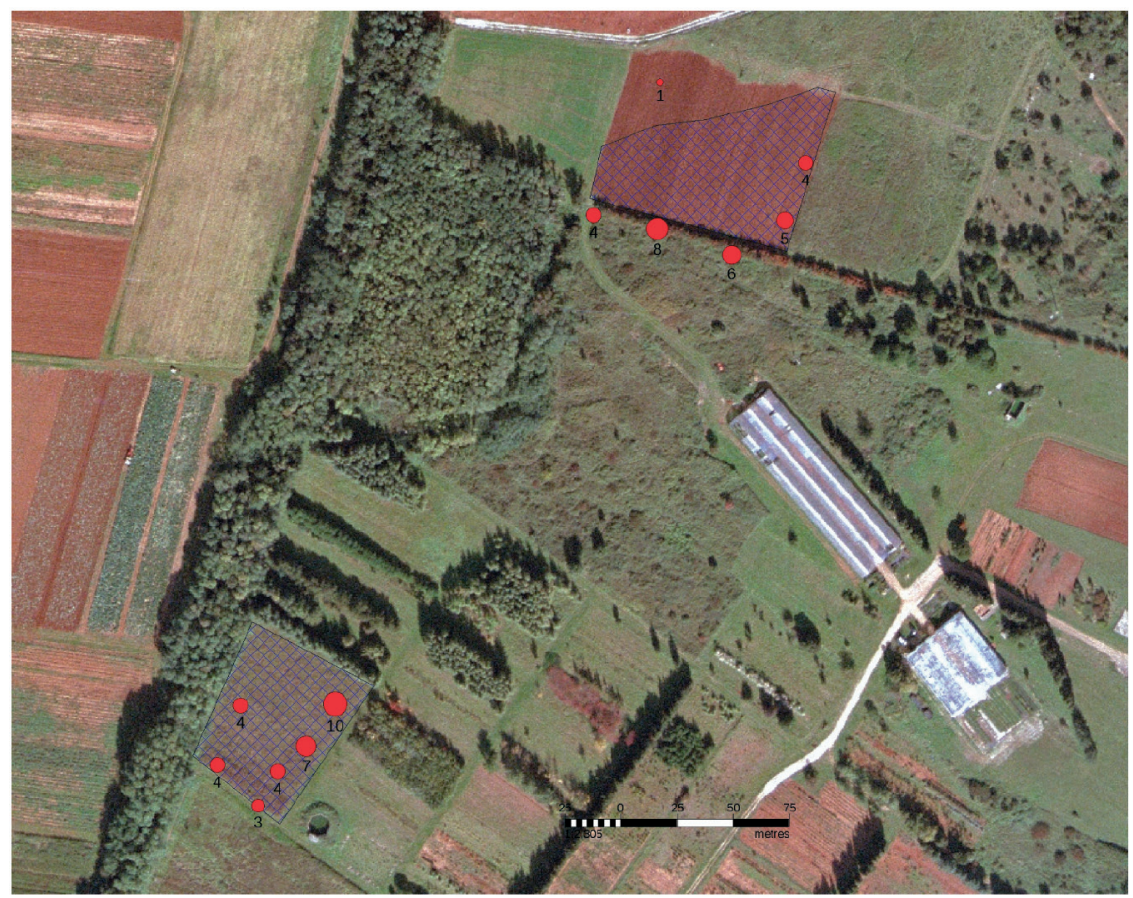

2) Frančeskija 1, 2

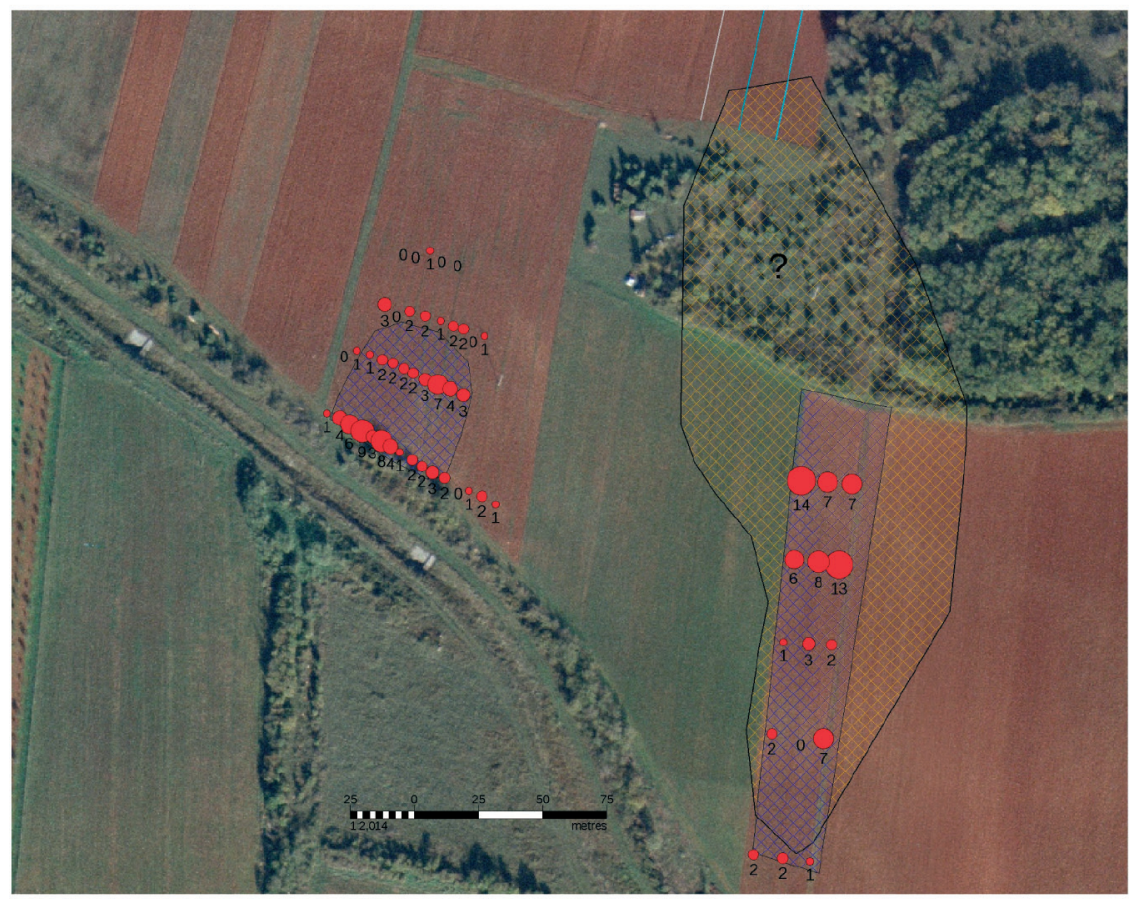

3) Jeci 1a, 1b 


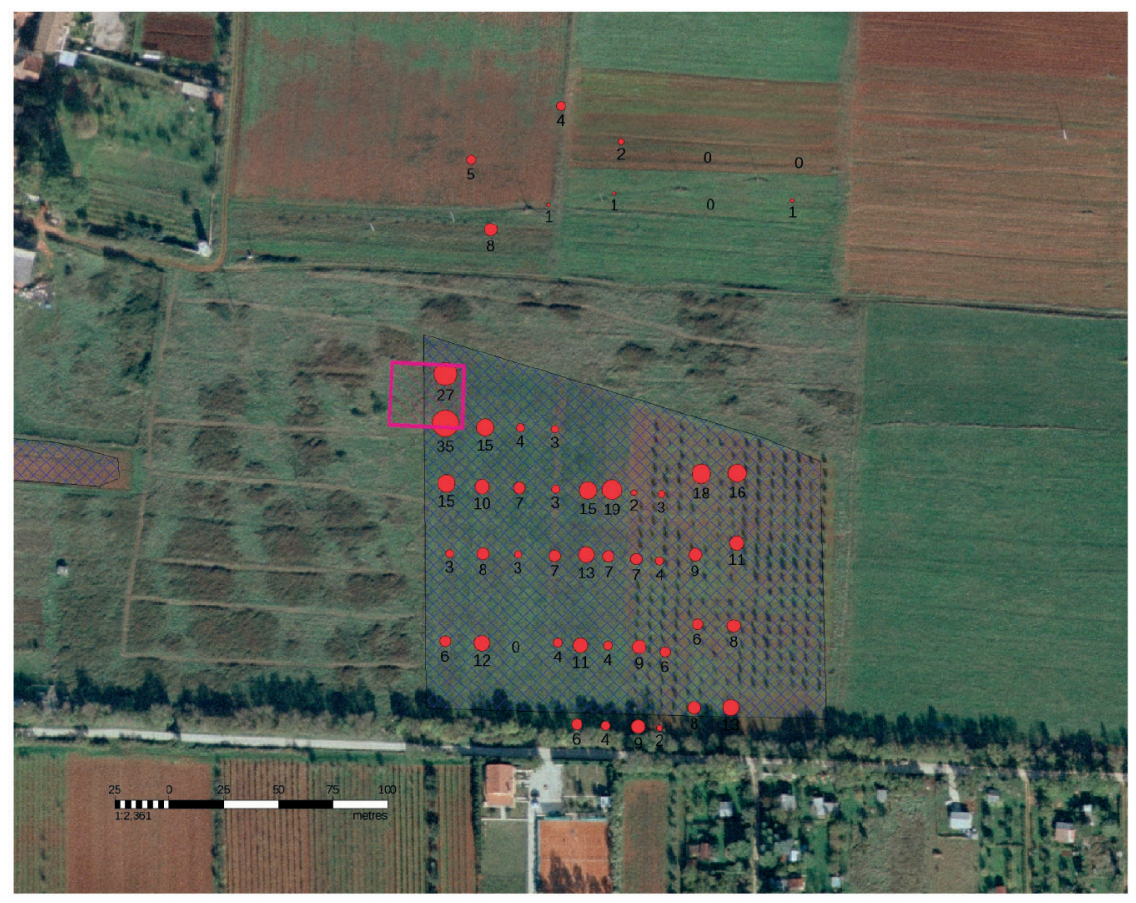

4) Seget 3

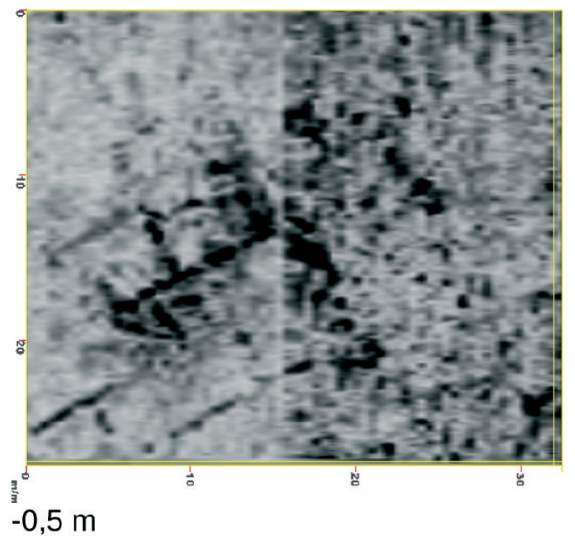

5) Seget 3 georadarski snimak

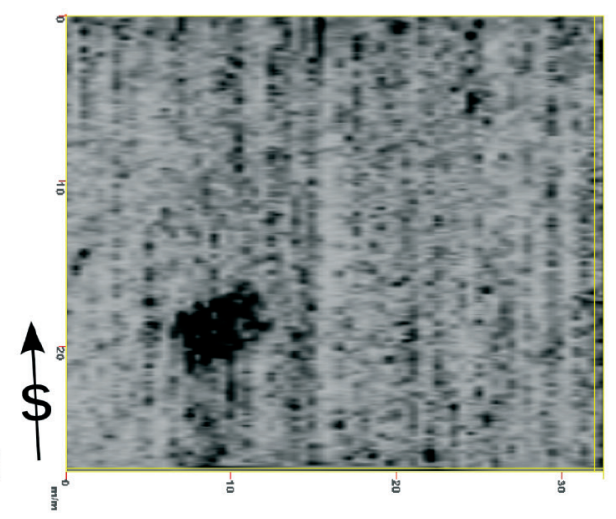

(Skelac 2009) 


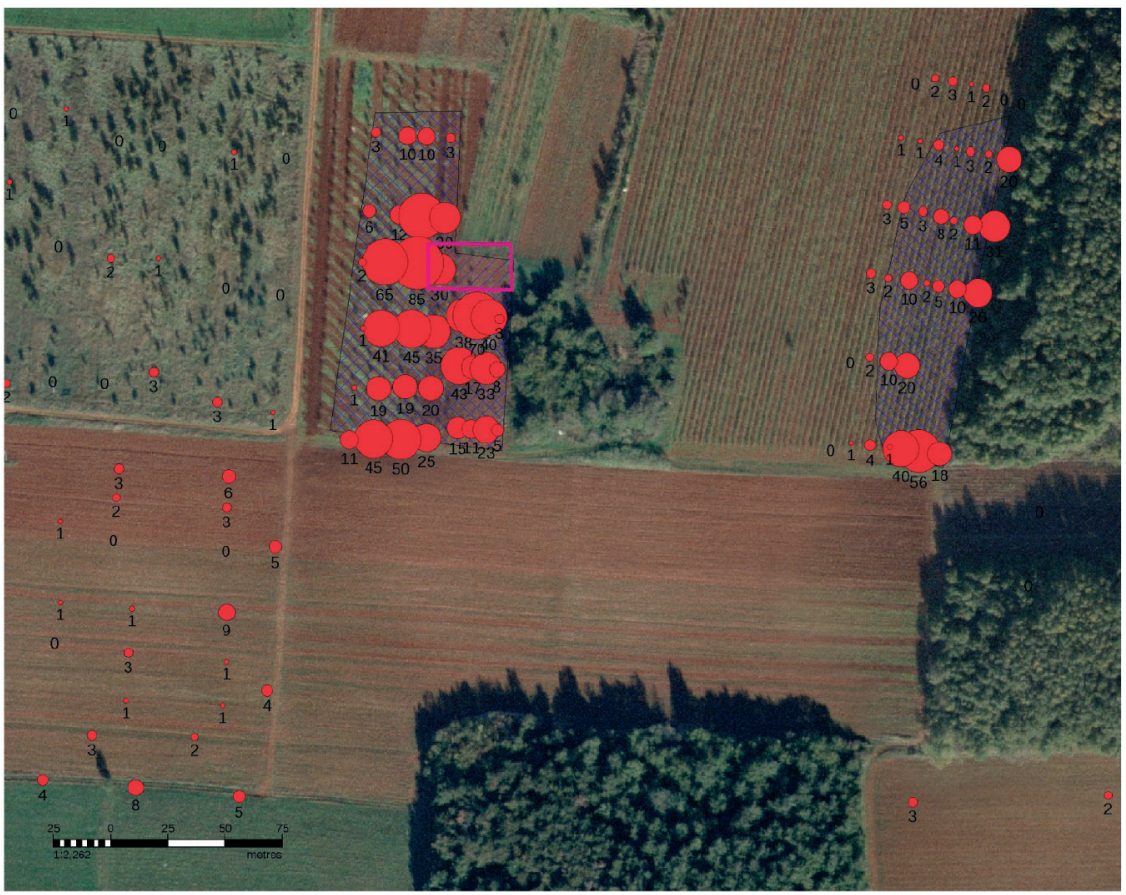

6) Makale 1, 2

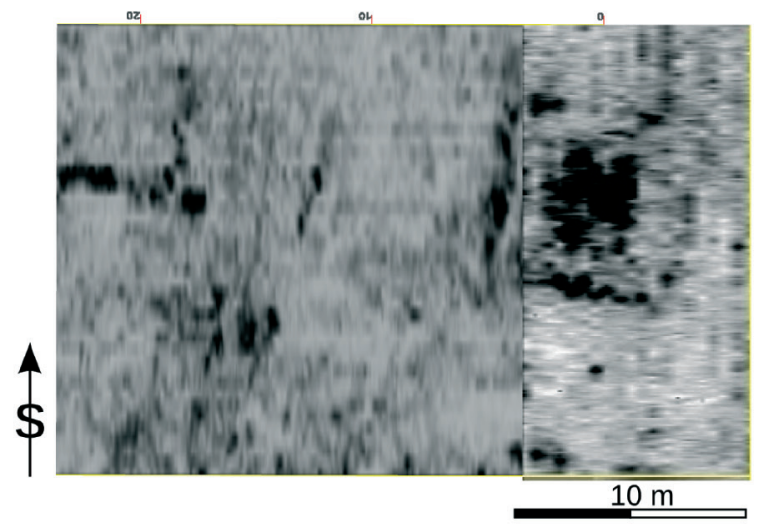

7) Makale 1: georadarski snimak

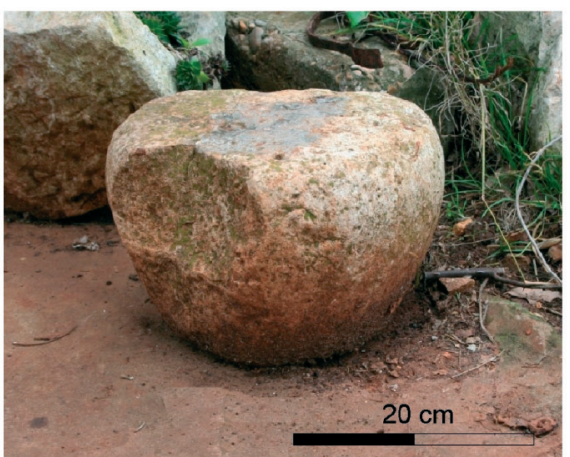

8) Uteg (?), naselje Makale 


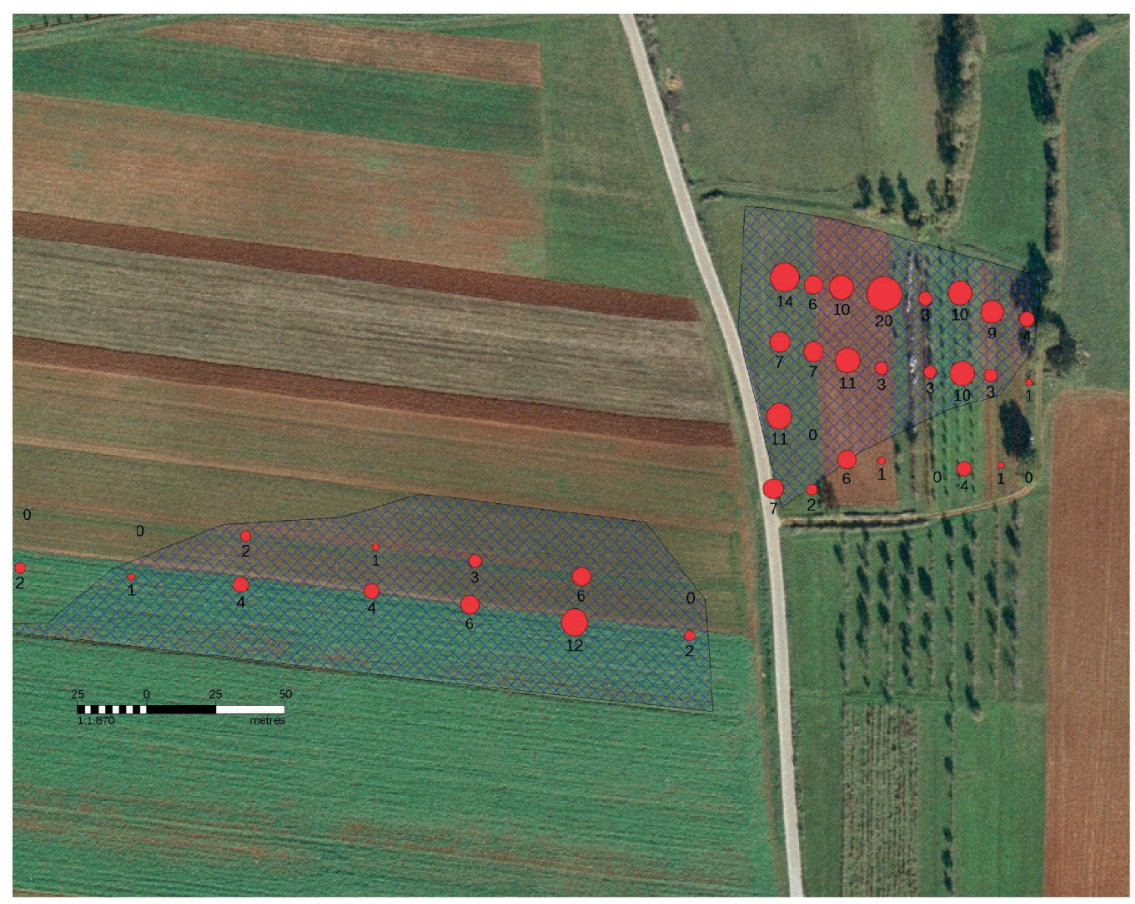

9) Jeci 3, Petrovija 1

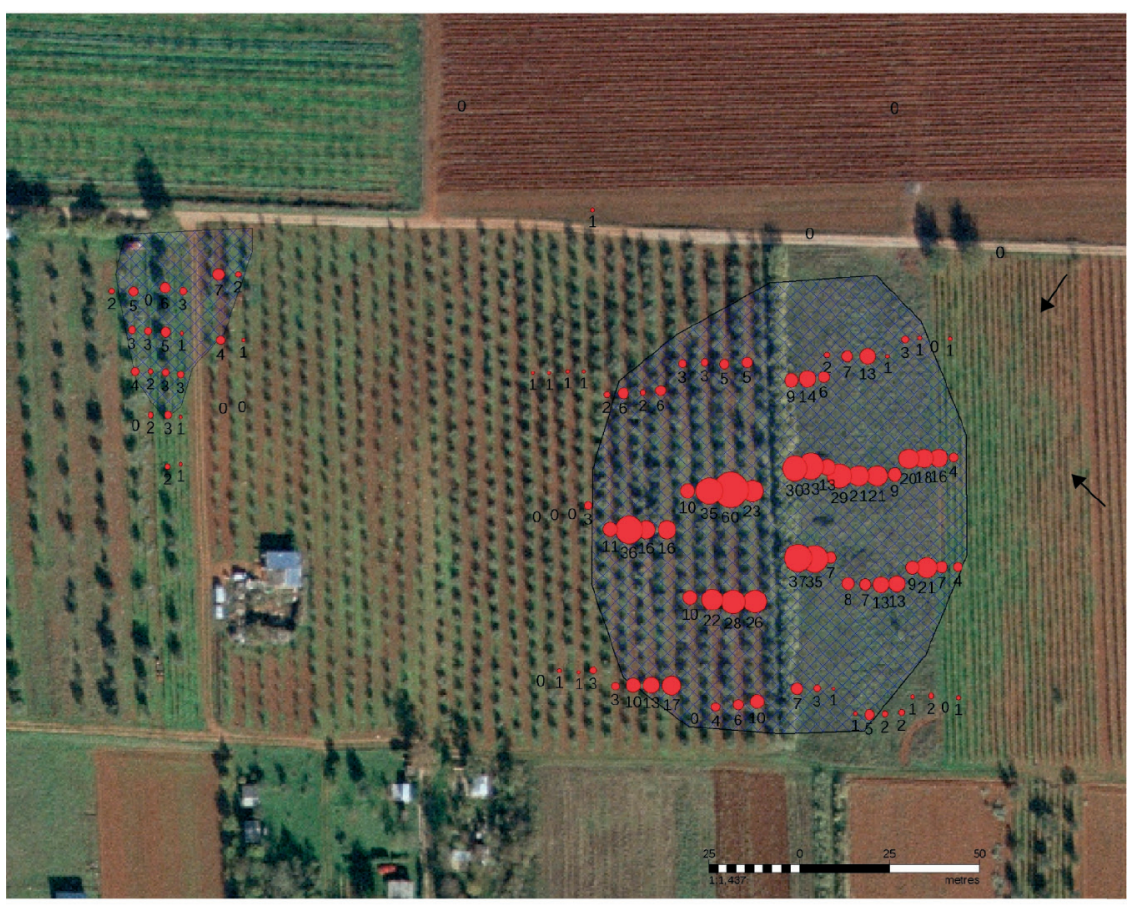

10) Makale 3, 4 


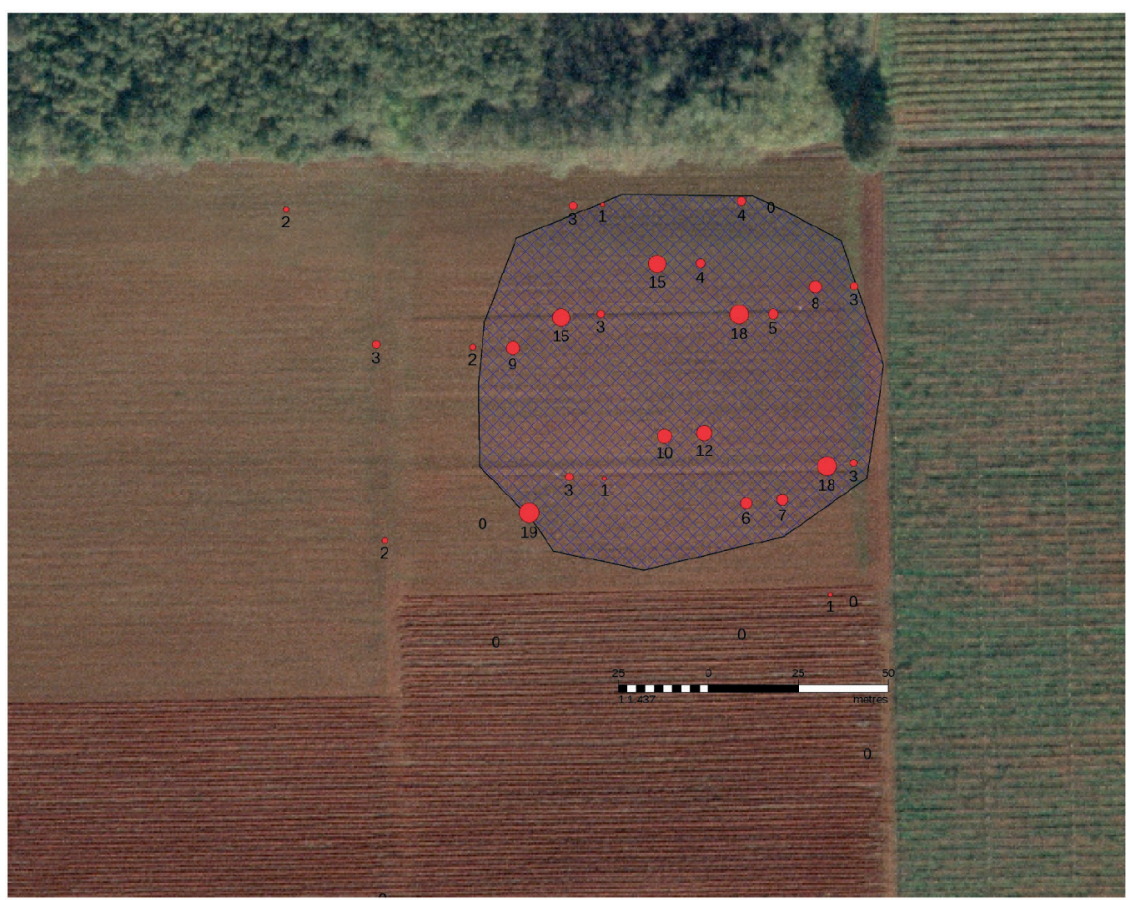

11) Makale 5

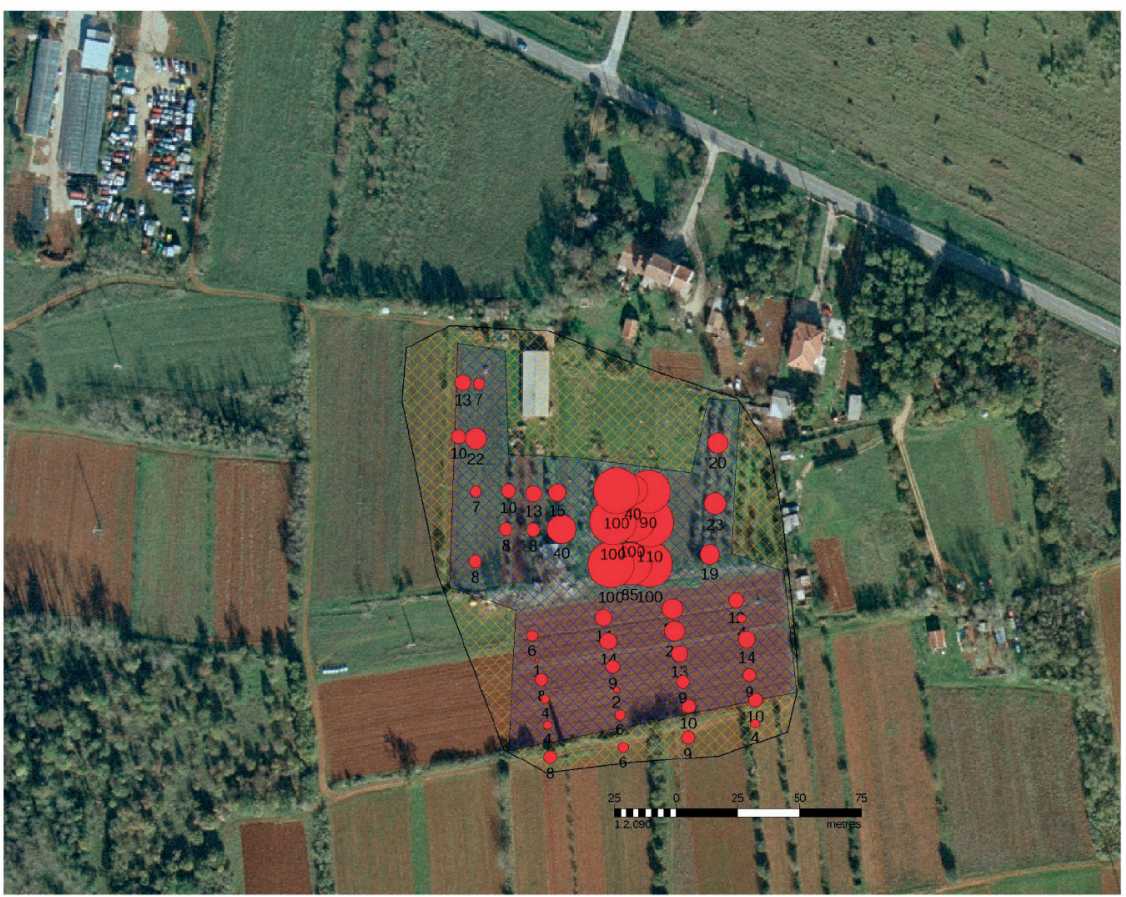

12) Petrovija 3 


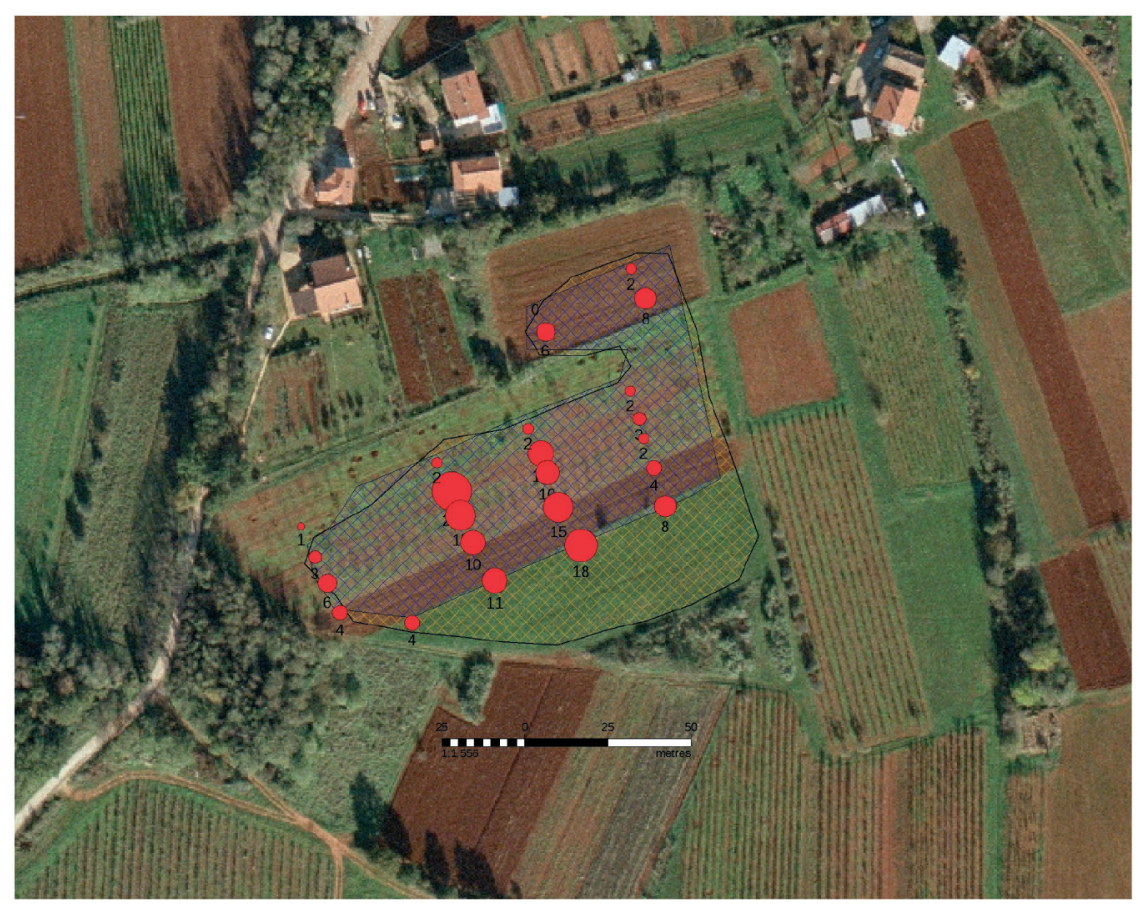

13) Petrovija 4

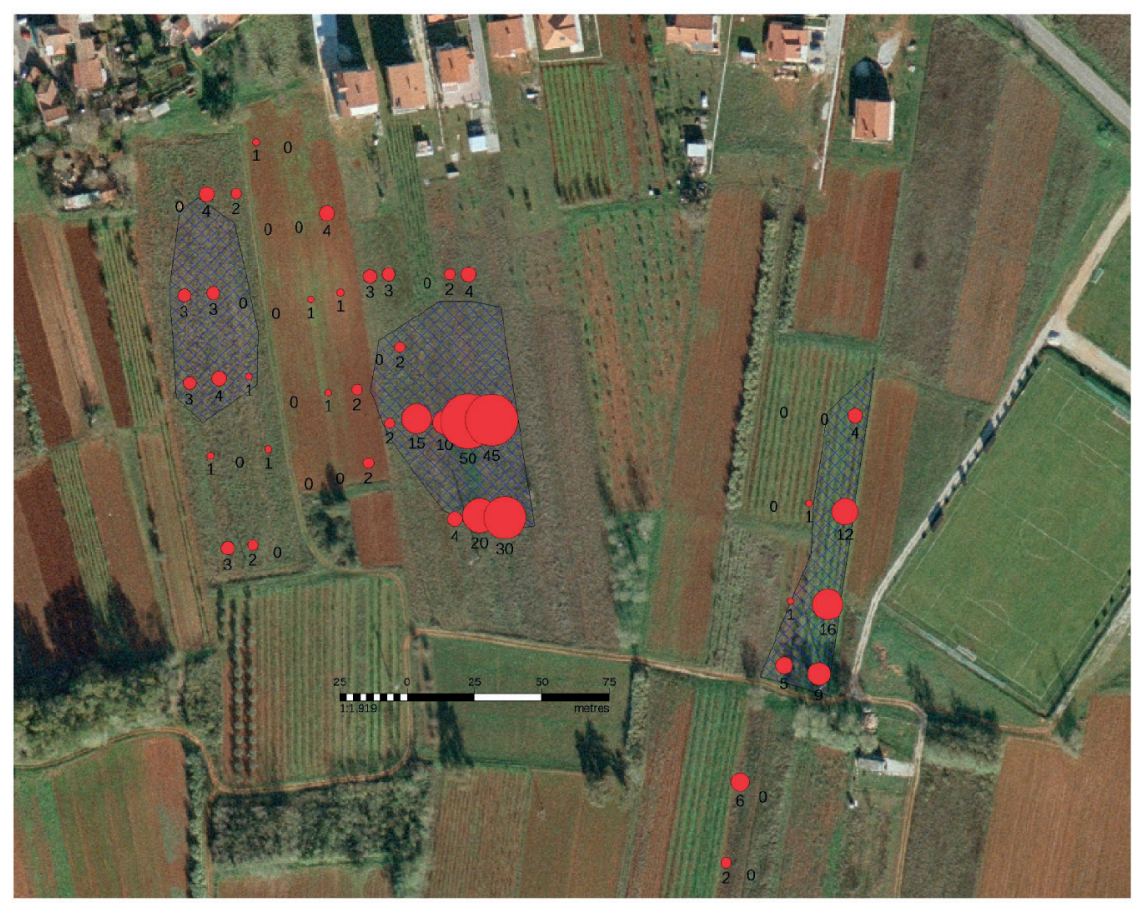

14) Petrovija 5, 6, 10 


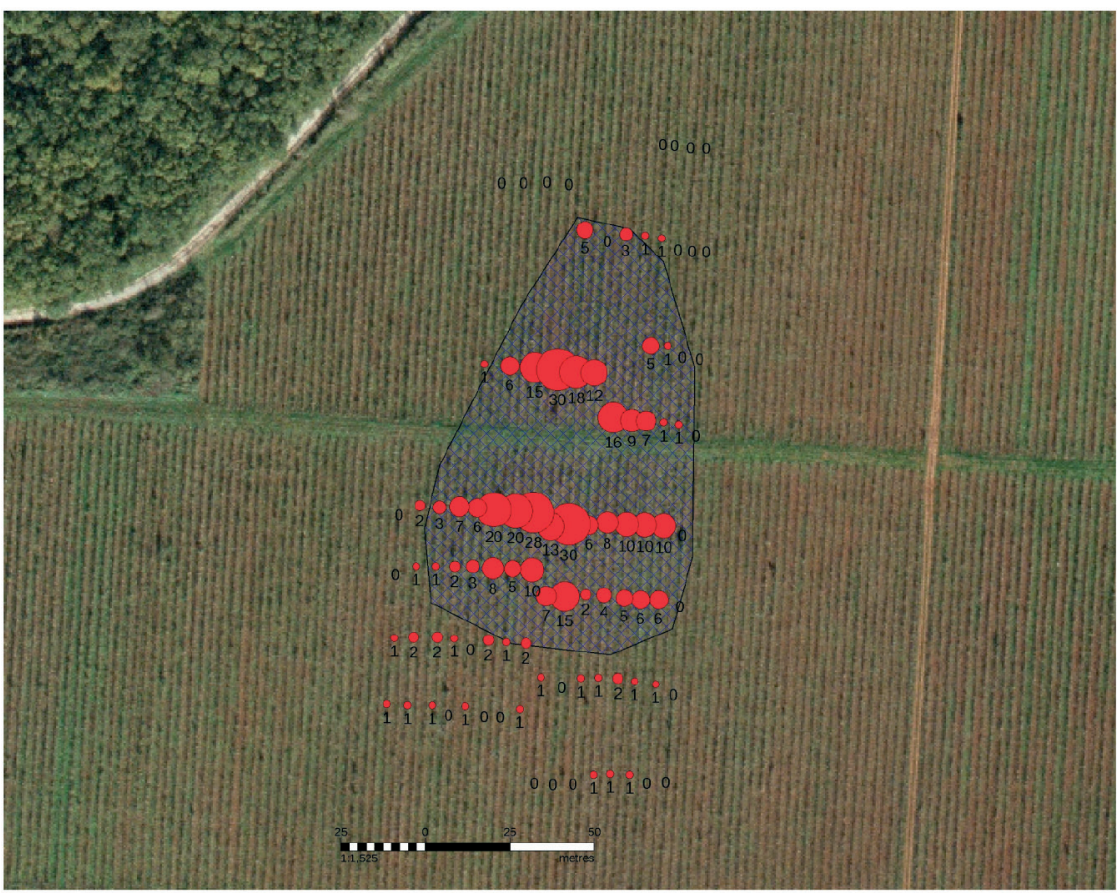

15) Petrovija 8

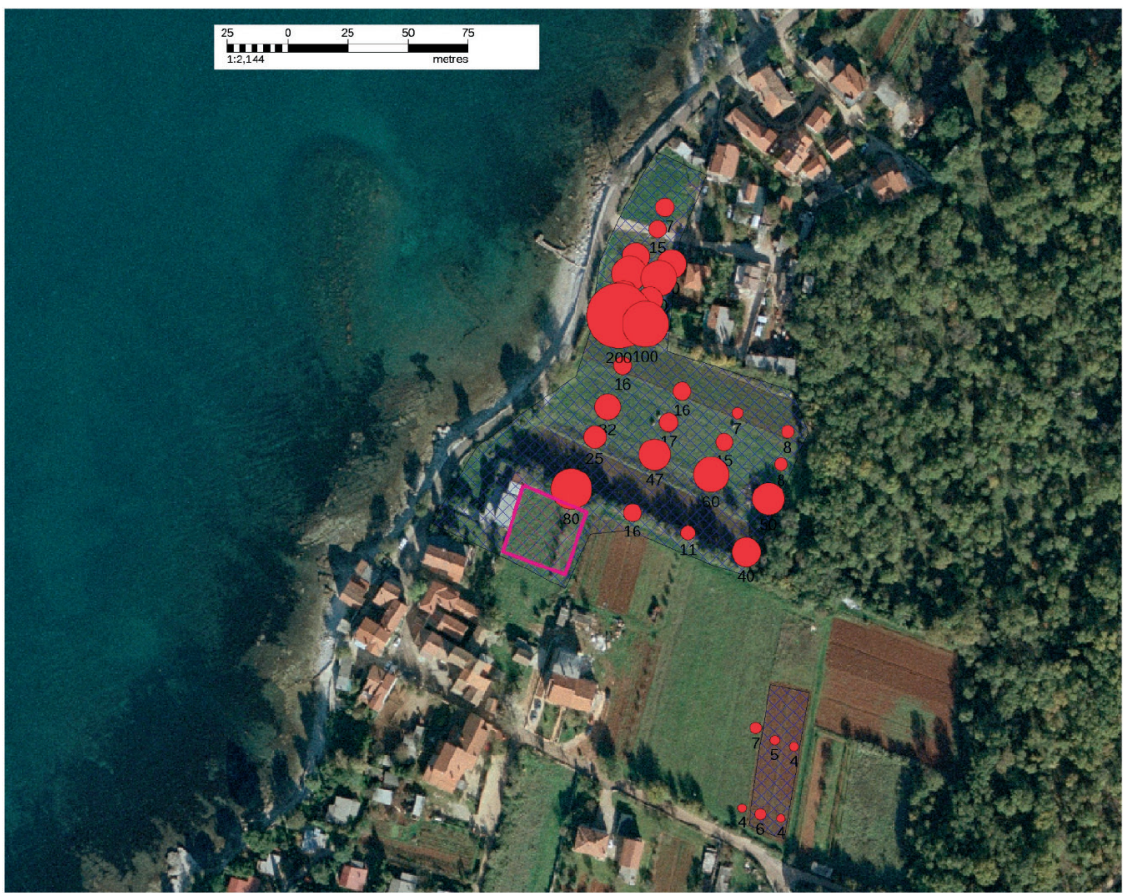

16) Sv. Ivan

Istražena arhitektura 


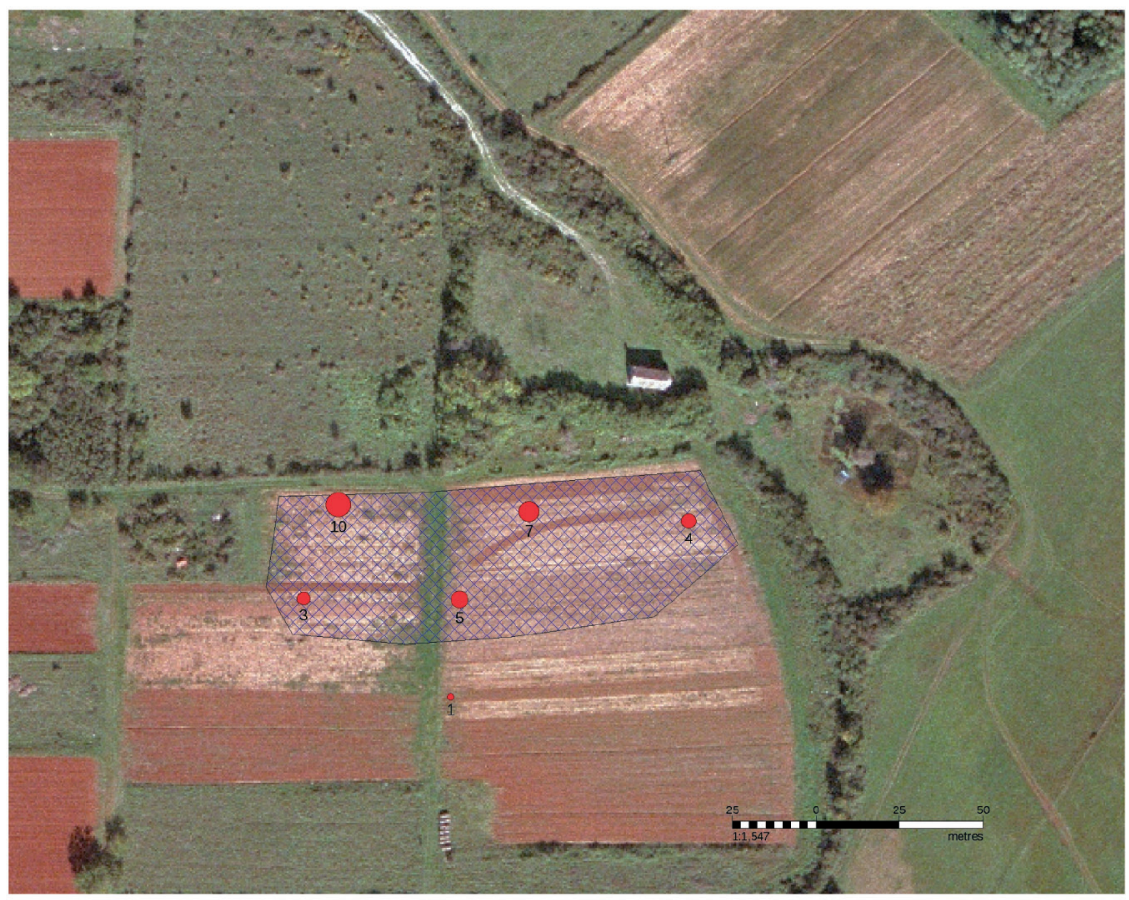

17) Valfontane 1

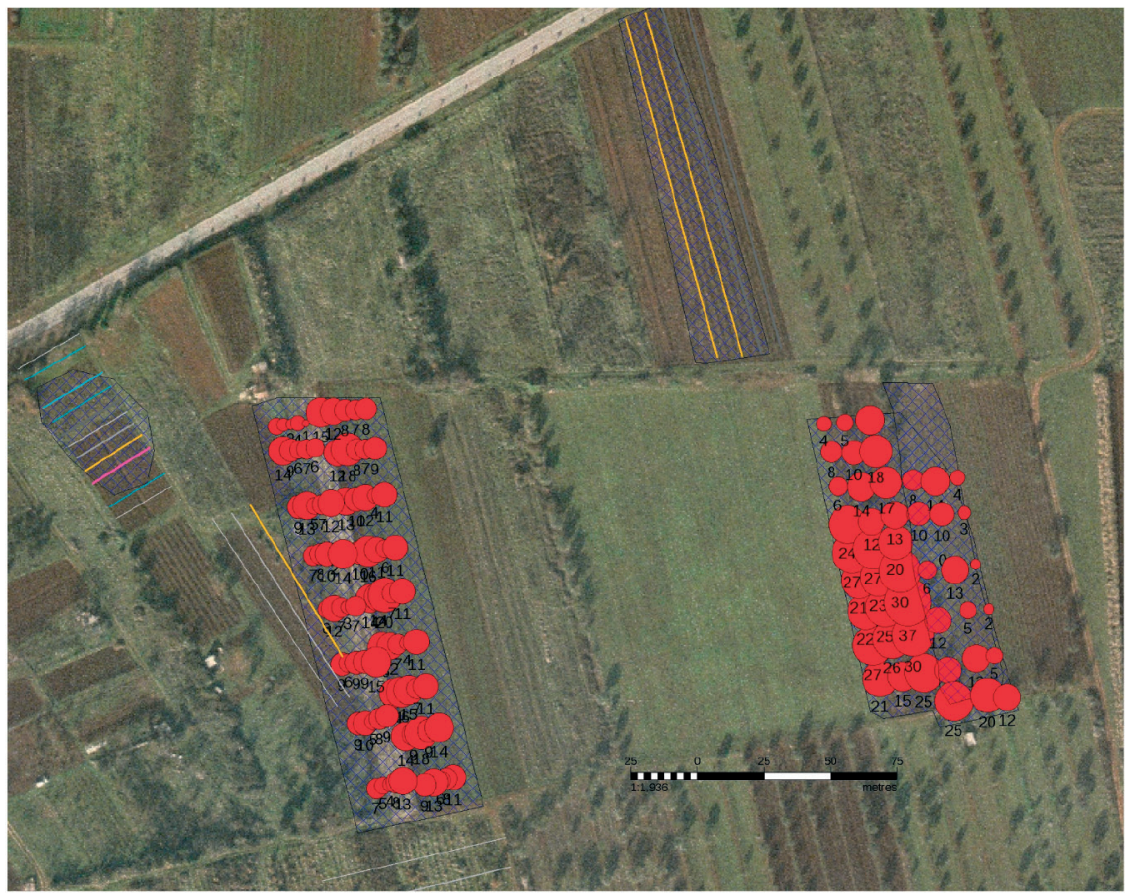

18) Vilanija 4 


\section{POPIS LITERATURE}

\section{BEKIĆ et al. 2008.}

Luka Bekić, Robert Čimin, Josiš Višnjić i Tihomir Percan, »Crveni Vrh«, Hrvatski arheološki godišnjak 4/2007, Zagreb 2008, 243-245.

\section{BENEDETTI 1973.}

Andrea Benedetti, Umago d'Istria nei secoli, vol I. Trieste 1973.

\section{BINTLIFF et al. 1989.}

John Bintliff, Vince Gaffney i Božidar Slapšak, »Kontekst in metodologija terenskega pregleda Ager Pharensis-Hvar«, Arheo, 9, Ljubljana 1989, 41-55.

\section{BINTLIFF 2000.}

John Bintliff, »The concepts of 'site' and 'offsite' archaeology in surface artefact survey", u: The Archaeology of Mediterranean Landscapes 4: Non Destructive Techniques Applied to Landscape Archaeology, (ur. Marinella Pasquinucci i Frédéric Trément) Oxford 2000, 200-215.

\section{BOLŠEC-FERRI 2008.}

Narcisa Bolšec-Ferri, »Zaštitno arheološko istraživanje na Trgu sv. Martina u Umagu 2004/2005 godine«, u: I. porečki susret arheologa: rezultati arheoloških istraživanja na području Istre: zbornik radova s međunarodnoga znanstvenog skupa održanog u Poreču 29. rujna 2006., (ur. Miljenko Jurković, Nikola Jakšić, Robert Matijašić), Poreč 2008, 105-109.

\section{BOLŠEC-FERRI 2007.}

Narcisa Bolšec-Ferri, »Lovrečica", Hrvatski arheološki godišnjak 3/2006, Zagreb 2007, 244-245.

\section{BRADANOVIĆ 2005.}

Marijan Bradanović, s.v. »Vilanija«, u: Istarska Enciklopedija, (ur. Miroslav Bertoša i Robert Matijašić), Zagreb 2005.

\section{BURŠIĆ-MATIJAŠIĆ 2007.}

Klara Buršić-Matijašić, »Gradine Istre : povijest prije povijesti«, u: Povijest Istre, knj. 6, Pula 2007.

\section{DE CAPELLARIS 1797.}

Giovanni Antonio de Capellaris, Carta dell'Istria, (cca 1:180.000), Trieste 1797.

\section{ČUČKOVIĆ 2008.}

Zoran Čučković, »Umag - šire područje«, Hrvatski arheološki godišnjak 4/2007, Zagreb 2008, 314-318.

\section{ČUČKOVIĆ 2010.}

Zoran Čučković, »Umag - šire područje grada«, Hrvatski arheološki godišnjak 6/2009, Zagreb 2010, 404-407.

\section{ČUČKOVIĆ 2010.}

Zoran Čučković, »Umag - lokaliteti Markovac, Kaštelir i Dajla«, Hrvatski arheološki godišnjak 6/2009, Zagreb 2010, 402-404.

\section{ČUČKOVIĆ (u tisku)}

Zoran Čučković, »Metodolgija sustavnog terenskog pregleda: primjer istraživanja zapadne Bujštine (Istra)« Opuscula archaeologica 36 (u tisku).

\section{ČIMIN 2007.}

Robert Čimin, »Kameni nalazi (Krvavići-Boškina)《, u: Zaštitna arheologija na magistralnom plinovodu Pula-Karlovac - Rescue archaeology on magistral gas pipeline Pula - Karlovac, (ur. Luka Bekić), Zagreb 2007, 133-138.

\section{DEGRASSI 1957.}

Atillio Degrassi, »l porti romani dell'Istria«, Atti e memorie della Società istriana di archeologia e storia patria n.s. 5, Trieste 1957, 24-81.

\section{DYSON 2003.}

Stephen L. Dyson, The Roman Countryside. London 2003.

\section{DŽIN 2007.}

Kristina Džin, »Pelićeti«, Hrvatski arheološki godišnjak 3/2006, Zagreb 2007, 256-259.

\section{GEORGES-LEROY et al. 2007.}

Murielle Georges-Leroy, Dominique Heckenbenner i Jean-Denis Laffite, »Les parcellaires anciens fossilisés dans les forêts lorraines«, u: La mémoire des forêts. Actes du colloque »Forêt, archéologie et environnement« 14-16 décembre 2004., (ur. JeanLuc Dupouey, Étienne Dambrine, Cécile Dardignac i Murielle Georges-Leroy), Metz 2007, 121-131.

\section{GRAMATICOPOLO 2004.}

Romano Gramaticopolo, »Via Flavia, strada romana nell'Istria romanizzata«, Archeografo triestino 64, Trieste 2004, 127-190.

\section{KATUNARIĆ 2009.}

Tea Katunarić, »Sv. Ivan Kornetski«, Hrvatski arheološki godišnjak 5/2008, Zagreb 2009, 371-376. 


\section{KOMŠO I ČUKA 2009.}

Darko Komšo i Maja Čuka, »Istarski ipsilon, čvor Umag - Kaštel«, Hrvatski arheološki godišnjak 5/2008, Zagreb 2009, 336-336.

\section{KOVAČIĆ I BRNIĆ 2009.}

Vladimir Kovačić i Želimir Brnić, »Stancija Portun kod Poreča«, Hrvatski arheološki godišnjak 5/2008, Zagreb 2009, 363-364.

\section{LEVEAU et al. 1993.}

Philippe Leveau, Pierre Sillières i Jean-Pierre Vallat, Campagnes de la méditeranée romaine, Paris 1993.

\section{MATIJAŠIĆ 1982.}

Robert Matijašić, »Roman Rural Architecture in the Territory of Colonia Iulia Pola«, American Journal of Archaeology 86 (1), Boston 1982, 53-64.

\section{MATIJAŠIĆ 1987.}

Robert Matijašić, »Topografija antičke ruralne arhitekture na obalnom području sjeverne Istre«, u: Arheološka istraživanja u Istri i Hrvatskom Primorju, Izdanja HAD 11, vol 2. (1986), Pula 1987, 75-98.

\section{MATIJAŠIĆ 1988.}

Robert Matijašić, Ageri antičkih kolonija Pola i Parentium, u: Latina et graeca, knjiga VI. Zagreb 1988.

\section{MATIJAŠIĆ 1997.}

Robert Matijašić, »Antička nekropola kod Brtonigle«, u: Arheološka istraživanja u Istri, Izdanja HAD 18, Zagreb 1997, 97-124.

\section{MATIJAŠIĆ 1998.}

Robert Matijašić, Gospodarstvo antičke Istre, u: Povijest Istre, knj. 4, Pula 1998.

\section{MATTINGLY 2000.}

David Mattingly, »Methods of collection, recording and quantification«, u: The Archaeology of Mediterranean Landscapes 5: Extracting Meaning form Ploughsoil Assemblages, (ur. Ricardo Franchovich i Helen Patterson), Oxford 2000, 5-15.

\section{MARKEŽIĆ-PETROVIĆ 2009.}

Biljana Markežić-Petrović, »Dajla«, Hrvatski arheološki godišnjak 5/2008, Zagreb 2009, 324-325.

\section{MILOTIĆ 2009.}

Ivan Milotić, Rimska vojnička diploma iz Umaga, Umag 2009.

\section{MLAKAR 1979.}

Štefan Mlakar, »Neki prilozi poznavanju antičke topografije Istre«, Histria archaeologica 10(2), Pula 1979, 9-42.

\section{ORTON 1980.}

Clive Orton, Mathematics in Archaeology, London 1980.

\section{POGLAJEN 2007.}

Sašo Poglajen, Geografski informacijski sistemi v študijah rimskega podeželja: primer severozahodne Istre (Doktorska disertacija). Ljubljana: Univerza v Ljubljani 2007.

\section{POGLAJEN 2009.}

Sašo Poglajen, »Simulation of the Roman road network in North-Western Istria«, Histria antiqua 17, Pula 2009, 229-240.

\section{RAYNAUD et al. 2009.}

Claude Raynaud, Hervé Pomarèdes i Yves Manniez, »Fermes gallo-romaines de la province de Narbonnaise«, u: Colloque AGER VIII - Toulouse 2007. Les formes de l'habitat rural gallo-romain. Términologies et typologies à l'épreuve des réalités archéologiques, (ur. Philippe Leveau, Claude Raynaud, Robert Sablayrolles i Frédéric Trément). Aquitania, Supp. 17, Bordeaux 2009, 141-165.

\section{SKELAC 2009.}

Goran Skelac »|zvještaj s georadarskog snimanja u okolici Umaga« (Neobjavljeni izvještaj, arhiva Muzeja grada Umaga).

\section{STARAC 1999.}

Alka Starac, Rimsko vladanje u Histriji i Liburniji I. (Histria), u: Monografije i katalozi 10, vol I. Pula 1999.

\section{STARAC 2002.}

Alka Starac, Istra od Epulona do Dioklecijana, Pula 2002.

\section{STARAC 2010.}

Alka Starac, »Arheološka istraživanja 2003-2004«, u: Dragonera, dva bisera - Dragonera, two pearls, (ur. Alka Starac), Monografije i katalozi 19, Pula 2010, 11-240.

\section{ŠKORIĆ et al. 1983.}

Arso Škorić, Branimir Mayer, Andrija Vranković i Ferdo Bašić, Pedološka karta Istre - Soil map of Istria (1: 150 000). Zagreb 1983. 
TASSAUX 2001.

Françis Tassaux, »Quatre sciecles de l'histoire d'une grande proprieté«, u: Loron (Croatie). Un grand centre de production d'amphores à huile istriennes: ler - IVe s. P.C., (ur. Françis Tassaux, Robert Matijašić, Vladimir Kovačić), Institut Ausonius, Memoires 6, Bordeaux 2001.

\section{TASSAUX 2012.}

Françis Tassaux, »Obalne vile i njihov fundus« $\mathrm{U}$ : Sjeverno priobalje poreštine $u$ antici, (ur. Marie Brigitte-Carre, Vladimir Kovačić i Françis Tassaux), Poreč 2012, 188-190.

\section{TAYLOR 2000.}

Jeremy Taylor, »Cultural Deposition Processes and Post-Depositional Problems«, u: The Archaeology of Mediterranean Landscapes, vol. 5: Extracting Meaning from Ploughsoil Assemblages, (ur. Ricardo Franchovich i Helen Patterson), Oxford 2000, 16-26.

\section{UJČıĆ 2005.}

Željko Ujčić, »Sv. Jelena«, Hrvatski arheološki godišnjak 1/2004, Zagreb 2005, 155-157.

\section{UJČIĆ 2007.}

Željko Ujčić, »Mala Šurida«, Hrvatski arheološki godišnjak 3/2006, Zagreb 2007, 273-274.

\section{UJČıĆ 2010.}

Željko Ujčić, »Kršete - Sv. Jelena«, Hrvatski arheološki godišnjak 6/2009, Zagreb 2010, 351-354.

\section{VRSALOVIĆ 1974.}

Dasen Vrsalović, Istraživanja i zaštita podmorskih arheoloških spomenika u SR Hrvatskoj - dosadašnji rezultati i prijedlozi za daljnji rad. Zagreb 1974.

\section{ZMAIĆ 2007.}

Vesna Zmaić, »Pličina Buje«, Hrvatski arheološki godišnjak 3/2006, Zagreb 2007, 259-260.

\section{SAŽETAK}

U radu su obrađeni rezultati sustavnog terenskog pregleda na području zapadne Bujštine u sjeverozapadnoj Istri, a težište je postavljeno na procjenu mogućnosti i ograničenja primijenjene metodologije u proučavanju antičkog arheološkog krajolika.

Sustavni terenski pregled umaške okolice je proveden u tri istraživačke kampanje (2007 - 2009 godine) u kojima je prekriveno oko 1600 ha. Dobiveni podaci su još uvijek vrlo fragmentarni, ali ipak pružaju razmjerno dobru podlogu za razmatranje antičkog kulturnog krajolika odnosno prednosti i nedostataka primijenjene metodologije.

Uspješnost terenskog istraživanja je razmotrena kroz usporedbu intenziteta pregleda i karakteristika dobivenog skupa podataka, naročito u kontekstu malih, slabo uočljivih lokaliteta. Formacijski procesi su analizirani kartiranjem tri osnovne agrarne zone na istraženom prostoru, pri čemu se najizrazitije razlike ispoljavaju kod područja pod industrijskim kulturama, tj. pod intenzivnom poljoprivrednom obradom.

Pronađena antička nalazišta su razvrstana u dvije osnovne skupine, veća nalazišta ili Tip A, vjerojatno dobrim dijelom klasične vile rustike, te manja nalazišta ili Tip B. Statističkom analizom je dokazana njihova prostorna korelacija. Razmotreni su, potom, određeni problemi arheologije krajolika. Prostorni raspored nalazišta je uspoređen s pedološkom kartom u svrhu razumijevanja lokalnog prirodnog konteksta. Naročita podudaranja nisu vidljiva u okviru istražene zone te je dokumentirani raspored protumačen kroz utjecaj lokalne komunikacijske mreže. Mogući teritorijalni odnosi su analizirani primjenom Voronojevog dijagrama, s posebnim osvrtom na metodološke i teoretske implikacije primijenjenog modela.

U konačnici su razmotreni tzv. nalazi izvan nalazišta (off-site archaeology) te ponuđene osnovne smjernice za njihovu interpretaciju. 


\section{SUMMARY \\ The ancient landscape of the Bujština region: the use of systematic field survey and an attempt at spatial analysis}

The article deals with the results of a systematic field survey of the western Bujština region (northwestern Istria). The problems with the use of survey methodologies are examined, along with the analytical potential of the approach for the study of the roman countryside.

The systematic field survey of Umag surroundings was made in three field campaigns (2007-2009), covering approximately 1600 ha. The data obtained are still fragmentary and incomplete, but nevertheless represent a relatively sound base for a preliminary analysis of the past countryside and of the methodological issues in the specific context of the Bujština region.

The success in the detection of archaeological sites is analysed by comparison of the composition of the obtained dataset, namely the ratio of small, poorly detectable sites with the intensity of field survey. Landscape formation processes are examined by mapping three main agricultural zones of the present countryside which reveals some marked correlations with the quality of the obtained data, especially in intensively cultivated areas where significant deterioration rates can be observed.

Documented roman sites have been classified into two broad groups, large sites or Type A, probably typical villae rusticae for the most part, and smaller sites or Type B. By the application of statistical analysis we have been able to demonstrate their spatial correlation. In order to provide an explanatory framework for the documented settlement pattern, several spatial analyses have been applied. Soil coverage has been mapped against the obtained dataset only to indicate that natural constraints on the site distributions are not prominent in the relatively flat study area. We have, then, turned to the possibilities of the impact of the local communication network on the settlement pattern, although conclusive results cannot be reached without a study in a larger regional context. Hypothetical territorial relationships are analysed by the application of Voronoy polygons (Thiessen cells), while special attention has been given to theoretical and methodological implications of the applied model.

In the last part the archaeological context of off-site finds is analysed. The explanatory model proposed, albeit in rather sketchy terms, relies upon multiple disposal patterns of archaeological material and is not primarily oriented towards the »manuring model«, which is otherwise commonly applied in systematic field survey accounts. 